\title{
Los deberes recíprocos de información en el contrato de seguro \\ Y especialmente el deber de información del asegurador frente al tomador del seguro
}

\author{
Andrés E. Ordóñez Ordóñez
}

\begin{abstract}
Sumario: Introducción- I. El deber de informacion del tomador del seguro frente al asegurador- A. Inconsistencias de la regulación del artículo 1058 C. Co.- B. El deber de información del tomador posteriormente a la celebración del contrato- II. El deber de informacion del asegurador frente al tomador del seguro y los mecanismos legales de carácter general que preservan ese deber- A. Mecanismos generales que preservan el deber de informacion del asegurador frente al tomador del seguro- B. Mecanismos particulares de protección al derecho a la información del tomador, utilizados en legislaciones extranjeras- C. Mecanismos consagrados en Colombia, a fin de preservar el derecho a la información por parte del tomador del seguro- III. El proyecto colombiano de estatuto del consumidor.
\end{abstract}

\section{INTRODUCCIÓN}

El interés específico por el análisis de los deberes recíprocos de información dentro del ámbito de las relaciones negociales, nace muy modernamente sin duda alguna frente al desarrollo de los contratos de adhesión y la constatación del creciente número de relaciones que surgen entre grandes empresarios que ejercen profesionalmente su actividad comercial frente al público consumidor, no familiarizado con los productos o servicios que requiere y le son proveídos por esos empresarios, ni con las condiciones de la competencia dentro del mercado en que los mismos se ofrecen.

Hoy en día es usual que el derecho a la información de los consumidores y usuarios de servicios se encuentre consagrado en normas de rango constitucional, como sucede en Colombia cuya Carta Política actual introduce en el artículo 78 la siguiente disposición: "La ley regulará el control de calidad de bienes y servicios ofrecidos y prestados a la comunidad, así como la información que debe suministrarse al público en su comercialización". Igualmente en declaraciones in- 
ternacionales de derechos y protección, tal como sucede en la Carta de Protección del Consumidor elaborada por el Consejo de Europa en 1973, que destaca entre los derechos fundamentales del consumidor el derecho a la información y a educación.

Es ya usual, por otra parte, la coordinación generalizada de esfuerzos a nivel de las agencias gubernamentales de control de la actividad económica, para imponer responsabilidades administrativas a las empresas que no cumplan cabalmente con los deberes de información frente al público, un esfuerzo que se desarrolla paralelamente con los que se hacen en el sentido de modernizar los mecanismos jurídicos necesarios para preservar el derecho a la información y sancionar el incumplimiento de los deberes recíprocos a este propósito, dentro del marco concreto de las relaciones contractuales aisladamente consideradas.

Antes del surgimiento de ese interés específico dentro del marco del moderno derecho del consumo, la disciplina de los deberes recíprocos de información en el ámbito contractual, cuando no estaba consagrada en fuente legal para ciertos y específicos casos, se involucraba dentro de conceptos más generales como el del abuso del derecho, la buena fe o el de los vicios del consentimiento, hasta el punto de que aún hoy se hace necesario rastrear en esos conceptos el origen y el significado de los desarrollos normativos concretos que esta institución tiene en el derecho comparado, y buscar en ellos también, por otra parte, la manera de hacer efectivo el cumplimiento de esos deberes recíprocos y las sanciones que corresponden a su incumplimiento, en legislaciones que, como la nuestra, todavía no tienen regulaciones específicas sobre la materia.

Dentro de este contexto, el tema que nos ocupa en esta oportunidad es la manera como se presenta este panorama frente al contrato de seguro, el estado actual de nuestra legislación al respecto, la procedencia de la aplicación en el caso del contrato de seguro de los mecanismos de preservación y protección del derecho a la información que puedan existir en el campo del derecho del consumo y los mecanismos que, con la perspectiva del derecho comparado, puedan resultar de aplicación útil para la disciplina del contrato entre nosotros, fijando particularmente la atención sobre los efectos que desde el punto de vista jurídico puede o debe tener el incumplimiento de los deberes recíprocos de información en el ámbito del seguro.

Debe señalarse de entrada que en el campo del derecho de seguros este tema de los deberes recíprocos de información tiene una relevancia especial por varias razones: 1 . Porque de tiempo atrás las regulaciones positivas del contrato de seguro han fijado la atención en un aspecto de esos deberes, que es el referido a la información que el tomador del seguro debe proporcionar al asegurador acerca de las circunstancias que rodean el estado del riesgo, previamente a la celebración del contrato, y sobre el mismo se ha construido una voluminosa doctrina jurisprudencial y de autores que constituye tema fundamental de los estudios de derecho de seguros; 2 . Porque tratándose de un contrato aleatorio, las soluciones 
que tradicionalmente y desde el punto de vista jurídico pueden darse frente a las violaciones a estos deberes recíprocos no resultan apropiadas en la mayoría de los casos y exigen un diseño especial, puesto que la privación total o parcial de los efectos del contrato, o su preservación, pueden significar un agravio económico superlativo para cualquiera de las partes, mucho más de lo que puede significar en un contrato conmutativo común y corriente. 3. Por la especial complejidad jurídica y técnica que presenta el contrato de seguro y que hace particularmente necesaria la adecuada información del tomador del seguro que es generalmente un profano en la materia y desconoce la especial disciplina de este negocio. 4. Por la intervención generalizada dentro del trámite de la contratación de los intermediarios de seguro, que constituyen una instancia adicional dentro del flujo de la información, cuyas funciones y responsabilidades plantean, por sí solas, una compleja problemática. Este aspecto se ve agravado hoy con la presencia de nuevas redes de distribución de seguros, diferentes a las tradicionales, que plantean nuevos interrogantes sobre la manera como puede garantizarse el derecho a la información de los tomadores, tema al que ha aludido el doctor AlEJANDRO VENEGAS en reciente estudio ${ }^{1}$.

A estas razones generales se agrega una muy particular y propia de la realidad colombiana, pero que es extensiva a países de similar desarrollo económico, y que consiste en la manifiesta dependencia de su actividad aseguradora de los mercados de reaseguro extranjeros, lo cual determina, a su vez, limitaciones protuberantes en lo que se refiere a la independencia con que las compañías de seguro pueden diseñar sus pólizas, las cuales resultan en un altísimo porcentaje de casos ser traducciones literales, a veces incomprensibles no solo desde el punto de vista del texto, sino de la realidad de nuestras instituciones jurídicas.

Las consideraciones expuestas anteriormente señalan a las claras que el análisis de los deberes recíprocos de información en el contrato de seguro resulta desde luego más interesante y novedoso en el sentido del deber de información que recae sobre el asegurador frente al tomador del seguro, puesto que el deber de información recíproco, del tomador para con el asegurador, tanto antes como después de la celebración del contrato, ha sido debidamente atendido en su regulación hasta el presente, y podemos decir que se encuentra suficientemente analizado en su alcance y en cuanto a las consecuencias de su incumplimiento. En otras palabras, en el campo del derecho de seguros, los deberes de información del asegurado, tanto en la etapa precontractual como en la etapa posterior a la celebración del contrato (agravación del estado del riesgo, coexistencia de seguros, alteraciones en el valor real del interés asegurado, siniestro, etc.), se encuentran debida y exhaustivamente tipificados en la ley, en cuanto a su contenido y en cuanto a las consecuencias de su inobservancia. Tienen, pues, una fuente legal clara; los

1 A. Venegas. "Evolución y perspectivas de la protección del asegurado", Memorias del VI Congreso Iberolatinoamericano de Derecho de Seguros, Cila 2000, Bogotá, 2000, 55 y ss. 
deberes de información del asegurador reposan en cambio en fuentes que pudiéramos llamar implícitas, acogiendo la discriminación que a este respecto suele hacer la doctrina. El profesor RuBÉN STIGLITZ señala a este respecto: "Otra categoría de reglas secundarias de conducta son aquellas cuya procedencia o fuente no es normativa y que se sustentan implícitamente en la buena fe y en lo que verosímilmente las partes entendieron o pudieron entender obrando con cuidado y previsión"

\section{EL DEBER DE INFORMACIÓN DEL TOMADOR DEL SEGURO FRENTE AL ASEGURADOR}

Como se anotó antes, en torno a este deber y su regulación abunda la actividad legislativa, doctrinaria y jurisprudencial en materia de contratos de seguro, y es un tópico que ha sido motivo de estudio profundo y sistemático durante años, hasta el punto que pudiera decirse que sobre el mismo no existen áreas inexploradas.

El artículo 1058 C. Co., resume una buena experiencia de derecho comparado sobre la materia y adopta sin dificultades la tendencia tradicional de ubicar el tema dentro de la teoría de los vicios del consentimiento, definiendo el ámbito del deber de información del tomador a las circunstancias que rodean el riesgo y determinan su intensidad, y sancionando el incumplimiento trascendente del deber de información del tomador con la nulidad del contrato de seguro, asociándolo claramente al vicio que el mismo genera en la manifestación de voluntad del asegurado.

Características destacadas de la regulación de esta materia en nuestro Código de Comercio son, por una parte, la discriminación que se hace en términos de la carga de la prueba, con referencia a la modalidad utilizada para producir la declaración sobre el estado del riesgo (con formulario o sin formulario propuesto por el asegurador), y por otra, la inhibición del efecto de nulidad del contrato ante la presencia de buena fe exenta de culpa (error inculpable) del tomador al incurrir en la inexactitud o en la reticencia, con transformación en una sanción mucho más benigna para dicho tomador que preserva al menos parcialmente los efectos del contrato.

Curiosamente, en este régimen de la inexactitud y reticencia del tomador en la declaración acerca del estado del riesgo, se puede ya evidenciar una particular preocupación de la ley por destacar el deber de información recíproco del asegurador, en la medida en que lo desfavorece visiblemente en caso de no orientar la declaración del tomador con un cuestionario específico acerca de las circunstancias que rodean el estado del riesgo, en términos de carga de la prueba. Al forzarlo a tener que demostrar una culpa del tomador en la declaración cuando no somete 
al mismo ese cuestionario, indiscutiblemente la ley está señalando cuán importante es para el asegurador, a la vez que es informado, informar también al declarante sobre los aspectos que él considera importantes en torno al estado del riesgo ${ }^{3}$.

No obstante, se pueden mencionar todavía algunas inconsistencias de la regulación de nuestro artículo 1058 C. Co., que vale la pena mencionar.

\section{A. Inconsistencias de la regulación del artículo 1058 C. Co.}

A pesar de que es indudable que los miembros de la comisión redactora del Código de Comercio en este punto hicieron un gran esfuerzo para tomar lo mejor de las experiencias del derecho comparado en esta materia y trasladarlas al texto legal, el artículo 1058 C. Co. colombiano presenta algunas inconsistencias que pueden resumirse así: 1 . Una evidente ambigüedad en la redacción, en cuanto se refiere a las consecuencias de la inexactitud referida a hechos no conocidos por el tomador, por cuanto, la inexactitud en sí misma considerada puede predicarse de circunstancias conocidas o no por quien hace la declaración y que implican simplemente discordancia con la realidad. 2. La circunstancia de que, bajo el entendido de la presunción de buena fe, aun de la buena fe exenta de culpa, la totalidad de la carga probatoria de la culpa, no solamente en el caso de declaración sin sujeción a formulario, sino cuando se trata de error inculpable del tomador, queda en cabeza del asegurador, y esto sin duda implica una presunción general $a b$ initio, de que toda inexactitud o reticencia son derivadas de error inculpable, lo que puede significar una ventaja injustificada en este caso para el tomador. 3. Una deficiente regulación del caso en que la inexactitud o reticencia implicaría contratación en términos menos onerosos y no ausencia de contratación, toda vez que la sanción en este caso puede resultar desproporcionada frente a la prima dejada de percibir por el asegurador. 4. Una dificultad manifiesta de aplicar la sanción en el caso de inexactitud o reticencia por error inculpable, cuando el contrato no se hubiera celebrado de no haber existido aquella, toda vez que entonces la prima que hubiera sido adecuada es imposible de establecer. 5 Un gran peligro de que se entienda saneada la inexactitud o reticencia, ante situaciones ambiguas que generen la desacertada conclusión de que ha existido una aceptación tácita por parte del asegurador o que éste "ha debido conocer" la circunstancia ocultada o manifestada en forma inexacta, tal como se puede observar en el caso de la sentencia de la Sala Civil de la Corte Suprema de Justicia del 2 de agosto de 2002, conforme a la cual es posible que un dolo comprobado del tomador pueda verse excusado por una culpa no bien determinada del asegurador.

3 Un análisis detenido sobre las cargas de información que existen para el asegurado, antes y después de la celebración del contrato de seguro, se hacen en la obra del mismo autor: Lecciones de derecho de seguros, t. III: "Obligaciones y cargas de las partes e inoperancia del contrato de seguro", Bogotá, 2004. 


\section{B. El deber de información del tomador posteriormente a la celebración del contrato}

Así como el artículo 1058 C. Co. hace referencia a la carga de información del tomador del seguro previamente a la celebración del contrato, la ley regula expresamente cargas de información adicionales que el tomador, el asegurado o el beneficiario, en su caso, deben cumplir con posterioridad a la celebración del mismo y aun después de la ocurrencia del siniestro. Nuevamente en este caso, como ya se dijo, la ley regula extensamente el contenido de la información que debe suministrarse en cada caso y las consecuencias que puede llegar a tener el incumplimiento correspondiente.

Carga de informar sobre la agravación del estado del riesgo (art. 1060 C. Co.). Carga de notificar al asegurador sobre los seguros coexistentes, antes de la ocurrencia del siniestro (arts. 1092 y 1093 C. Co.). Carga de informar acerca de la ocurrencia del siniestro (art. 1075 C. Co.). Carga de informar la coexistencia de seguros posteriormente a la ocurrencia del siniestro (art. 1076 C. Co.). Carga de información necesaria para que el asegurador pueda ejercer su derecho a la subrogación (art. 1098 C. Co.). Carga de informar acerca de la trasmisión o transferencia del interés asegurable (arts. 1106 y 1107 C. Co.).

\section{EL DEBER DE INFORMACIÓN DEL ASEGURADOR FRENTE AL TOMADOR DEL SEGURO Y LOS MECANISMOS LEGALES DE CARÁCTER GENERAL QUE PRESERVAN ESE DEBER}

La dificultad fundamental de establecer la existencia y los alcances del deber de información del asegurador frente al tomador del seguro consiste en que, como ya se dijo, no existen desde luego actualmente reglas específicas en la regulación del contrato de seguro que se refieran al mismo, ni se encuentran señaladas sanciones dirigidas a la preservación de ese deber, distintas a las que establecen algunos requerimientos formales de la póliza de seguro o a las que consagran normas de conducta empresarial, cuya omisión es susceptible de generar responsabilidades de tipo administrativo para entidades vigiladas por la Superintendencia Bancaria. Es claro que un mecanismo real de preservación del deber de información del asegurador y del correlativo derecho a la información por parte del asegurado debe reflejarse en los efectos mismos del contrato, para que el acreedor de la información, que es en este caso el tomador del seguro, se encuentre realmente protegido.

No obstante la inexistencia de normas específicas en nuestro ordenamiento jurídico, debe aceptarse que el deber de información del asegurador frente al tomador de seguro forma parte de los llamados deberes secundarios de conducta que imponen las reglas de convivencia y solidaridad social implícitas en la actividad contractual de los particulares, deberes secundarios que existen respecto de 
cualquier contrato pero que resultan particularmente importantes dentro del contexto del contrato de seguro por las razones que han sido expuestas ${ }^{4}$.

¿En qué consiste y ¿cuál es la oportunidad del deber de información del asegurador al tomador dentro del contrato de seguro?

El deber de informar que cabe al asegurador dentro del contrato de seguro, es un deber que, como en la mayoría de los casos, ha de ser cumplido, fundamentalmente y en principio, en la etapa previa a la celebración del contrato, y el cumplimiento cabal o defectuoso del mismo, o su incumplimiento, se proyectan necesariamente en la etapa posterior a la celebración del contrato. Como se verá a espacio más adelante, este deber de información no se concreta en el caso del contrato de seguro, como en el caso de los demás contratos sinalagmáticos, en la finalidad de que la manifestación de voluntad del otro contratante, el tomador, se produzca sin vicios, sino fundamentalmente en que puedan aplicarse cabalmente todas las condiciones del contrato, y particularmente, entre ellas, las que favorecen o son útiles al asegurador dentro del contexto del carácter de adhesión que justamente se asigna al contrato de seguro.

Podemos señalar desde ahora algunos aspectos de la relación contractual sobre los cuales es claro pensar que asiste al asegurado especial interés en estar adecuadamente informado, previamente a la celebración del contrato; el toamdor tiene, pues, especial interes en:

1. Ser informado cabalmente del alcance real de las coberturas que recibe. Para esos efectos, existe una exigencia específica de ley en materia de seguros, que consiste en que la identificación de los riesgos en las pólizas de seguro deben estar contenidas en la primera página de las mismas ${ }^{5}$.

2. Conocer cabalmente los condicionamientos a que se encuentran sometidas esas coberturas, a partir de la existencia de obligaciones y cargas de su parte que deben ser cumplidas y que conforman una compleja red de interacciones que está plasmada normalmente en la ley y no en el contrato, que vinculan en consecuencia al tomador puesto que la ignorancia de la ley jamás puede considerarse excusa válida para su incumplimiento ${ }^{6}$, y que no obstante requiere de conocimientos muy especializados en la materia que no están al alcance de todos.

4 AA. VV. Contratos. Teoría general, t. I, R. Stiglitz (dir.), Buenos Aires, 1990, 459: "Pensamos que más allá de los deberes primarios de prestación que específicamente corresponden al modelo contractual seleccionado por las partes, típico o atípico, y que son propios y estrictamente los que corresponden al tipo elegido, existen reglas secundarias de conducta o deberes accesorios a los principales que, pactados o no o de procedencia legal, constituyen contenido de la obligación. Se trata de deberes derivados del principio superior de buena fe y de la estipulación implícita de que lo acordado por las partes se integra, además de lo expresado, con lo que verosímilmente entendieron o pudieron entender obrando con cuidado y previsión".

5 Literal b numeral 2 artículo 184 del Estatuto Orgánico del Sistema Financiero: "Los amparos básicos y las exclusiones deben figurar, en caracteres destacados en la primera página de las pólizas".

6 Arts. 768 inciso $4 .^{\circ}$ y 1509 C. C. Y sin embargo vale la pena consultar a este respecto 
3. Tener información sobre los límites cuantitativos que tiene la responsabilidad del asegurador en caso de siniestro, y particularmente las consecuencias que tiene la presencia de infraseguro o sobreseguro en los seguros de daños.

4. Conocer las circunstancias más determinantes de la intensidad del riesgo que asume el asegurador, con vistas a la declaración que sobre las mismas debe hacer el tomador y a la carga que tiene de conservar el estado del riesgo a lo largo del contrato.

5. Saber de los mecanismos legales de carácter general que protegen en el derecho colombiano el derecho a la información y señalan el deber de informar adecuadamente, por parte del asegurador, al tomador del seguro.

6. Estar al tanto de la extensión de las facultades de sus funcionarios o de los intermediarios, cualquiera que sea su naturaleza, que actúan por encargo suyo en la etapa precontractual.

7. Conocer los condicionamientos que puede tener la iniciación de la vigencia del contrato de seguro.

No obstante, el deber de información por parte del asegurador puede igualmente requerirse con posterioridad a la celebración del contrato para ciertos efectos. La ley española, por ejemplo, hace una exigencia particular a este respecto. "Así, el artículo 60 de la nueva Ley de Supervisión y Ordenación exige el deber informativo antes de celebrar un contrato de seguro distinto al seguro de vida y durante todo el periodo de vigencia del contrato de seguro sobre la vida; para lo cual, se exige además a la empresa aseguradora que deberá informar al tomador de las modificaciones de la información inicialmente suministrada y asimismo, en los términos que reglamentariamente se determinen, en todo caso con periodicidad anual, sobre la situación de su participación en beneficios" ${ }^{17}$.

Pero en general, es razonable considerar que el asegurador tiene un deber de información que le impone el principio general de la buena fe, posteriormente a la celebración del contrato en lo que se refiere: 1 . A una adecuada orientación de su asegurado en el proceso de reclamación en caso de siniestro, que se hace particularmente importante en un medio como el nuestro en que es notorio que las aseguradoras son proclives a volver interminables los trámites de reclamación. A este respecto debe mencionarse la existencia de dos normas que aluden al menos indirectamente a este deber: el artículo 1053 C. Co., que al consagrar el mérito ejecutivo de la póliza se refiere a los "comprobantes que, según las condiciones de la correspondiente póliza, sean indispensables para acreditar los requisitos del artículo 1077", y el artículo 100 del Estatuto Orgánico del Sistema Financiero, que en su numeral 3 consagra como prácticas prohibidas a las compañías de se-

las juiciosas advertencias de G. Escobar Sanín. Negocios civiles y comerciales, t. II, 1994, 98 y ss.

7 E. Caballero Sánchez. El consumidor de seguros. protección y defensa, Colección Estudios y Monografías, Madrid, 1997, 71. 
guro susceptibles de generar la revocación del certificado de autorización de funcionamiento para el asegurador, entre otras, "la exigencia de formalidades no previstas legalmente para acceder al pago de las indemnizaciones y toda práctica que de manera sistemática tenga como propósito evitar o dilatar injustificadamente el cumplimiento de las obligaciones nacidas del contrato de seguro". 2. A una igualmente adecuada información al asegurado, en caso de seguros múltiples o en caso de existencia de varios seguros cubriendo riesgos similares, acerca de cuál es la cobertura aplicable al siniestro ocurrido y la que de manera más cabal cubre el interés asegurable. Lo anterior, toda vez que también en estos casos el asegurador actúa conscientemente en detrimento de su deber de lealtad y buena fe, cuando, valiéndose de la complejidad de las definiciones técnicas del riesgo, deja al asegurado sumido en la indecisión sobre la cobertura con base en la cual debe formular su reclamo, frente a varias posibles, con consecuencias económicas que pueden llegar a ser muy adversas, y 3. A una información adecuada sobre los términos en que puede producirse la renovación del contrato, para el caso frecuente en que el asegurado requiera mantener las coberturas hacia futuro.

\section{A. Mecanismos generales que preservan el deber de informacion del asegurador frente al tomador del seguro}

\section{El principio de la buena fe}

Es indudable que el deber de información que asiste a las partes en general, dentro del marco de cualquier relación contractual, se inscribe en primer lugar dentro de la obligación de obrar con buena fe exenta de culpa en la etapa precontractual, tal como está consagrada entre nosotros por el artículo $863 \mathrm{C}$. Co. Es sabido que esta consagración positiva en la ley colombiana data de 1971 cuando se puso en vigencia el Código de Comercio actual, toda vez que el Código Civil no se refirió expresamente al principio de la buena fe en esta etapa del contrato, sin perjuicio de que puedan encontrarse aplicaciones jurisprudenciales de la misma con anterioridad.

Las tendencias doctrinarias más reconocidas admiten la estrecha relación que existen entre el principio de la buena fe y los deberes recíprocos de información en el contrato; así, por ejemplo, RuBÉN STIGLITZ afirma: "Las reglas secundarias de conducta son manifestaciones de la buena fe contractual, y se constituyen en el carácter más saliente de esa buena fe pues, como directiva de interpretación o como criterio de comportamiento, no se agotan con la ejecución de las prestaciones principales o de las accesorias, sino que, en su formulación, atrapan la conducta de cada parte como unidad desde las tratativas que preceden al perfeccionamiento del contrato, hasta el periodo postcontractual, inclusive ${ }^{\prime \prime}$. 
Ahora bien, independientemente de su innegable vinculación originaria con el principio de la buena fe, y de los deberes recíprocos de información que existen en el ámbito del contrato, como una manifestación de la lealtad y la solidaridad que debe privar en una relación de colaboración como la que supone cualquier contrato, forzoso es registrar el hecho que un comportamiento contrario a la buena fe exenta de culpa en la etapa precontractual, supone para el contratante que lo protagoniza una imputación de responsabilidad civil en la modalidad de extracontractual.

No obstante, la posibilidad de una acción de responsabilidad extracontractual del tomador contra el asegurador, fundada en la ausencia de buena fe exenta de culpa en la etapa precontractual por violación del deber de información, resulta difícil de tipificar en la práctica en la medida que, en ausencia del contrato, mal podría concebirse la causación de un daño al tomador por incumplimiento o cumplimiento defectuoso del deber de información del asegurador en torno a los alcances de la cobertura o a los demás aspectos relevantes de la disciplina interna del contrato. En general, puede decirse que la responsabilidad extracontractual por ausencia de buena fe en la etapa precontractual está limitada a los eventos en que precisamente el error de conducta que se imputa al autor del daño está íntimamente relacionado con la frustración del contrato; y por ello, no obstante no ser extraña a nuestra práctica judicial la existencia de litigios por responsabilidad extracontractual dirigidos contra compañías de seguro por culpa en la etapa precontractual, esos litigios no se originan en ningún caso en el incumplimiento de los deberes de información, sino, en la mayoría de los casos, en demoras injustificables en el trámite de las solicitudes de seguro, o en el hecho, en general, de haberse producido un siniestro que habría estado cubierto por la póliza de seguro, antes de haberse celebrado el contrato, en circunstancias en que la etapa precontractual se hubiera prolongado innecesariamente por culpa del asegurador o del intermediario de seguros ${ }^{9}$.

Podría concebirse, al menos hipotéticamente, una acción de responsabilidad civil extracontractual contra el asegurador por violación a sus deberes de información, en el caso de que el contrato de seguro finalmente no se hubiese celebrado, por no haber informado adecuadamente al tomador del seguro acerca de las verdaderas facultades con las que actuaban sus funcionarios o intermediarios dentro de la etapa precontractual, omisión que hubiera podido llevar a pensar al tomador que el contrato de seguro había nacido a la vida jurídica sin corresponder ello a la realidad. No obstante, en este caso cabría posiblemente la configuración de un mandato aparente, de demostrarse efectivamente un error de conducta en esta materia por parte del asegurador, que daría una mayor ventaja

9 Caso característico fue el estudiado por la Sala de Casación Civil de la Corte en sentencia del 9 de noviembre de 1982, proferida dentro del proceso ordinario de María Josefa Arteaga de Camargo contra Capitalizadora Grancolombiana S. A. 
al tomador defraudado en este evento. Otra posibilidad estaría dada en el caso de retiro abrupto e intempestivo de las tratativas o de revocación de una oferta válidamente formulada ${ }^{10}$, pero en estos casos no parecen clara o necesariamente comprometidos los deberes recíprocos de información de las partes.

Las infracciones al deber de información en la etapa precontractual por parte del asegurador frente al tomador del seguro no podrían sancionarse en consecuencia, al menos claramente, a través de las acciones de responsabilidad extracontractual, a menos que las mismas estuvieran asociadas a la frustración misma del contrato de seguro tentado o proyectado, por lo cual deberá buscarse una sanción más concreta a dicha infracciones dentro de la proyección que, como se ha visto, las mismas tienen ya en la etapa contractual una vez nacido el acuerdo a la vida jurídica ${ }^{11}$.

¿Puede bajo los principios reguladores de la buena fe contractual, aplicados en forma autónoma, sancionarse la infracción al deber de información por parte del asegurador previamente a la celebración del contrato, ya una vez celebrado este? Es un planteamiento que ha sido expuesto por JAVIER TAMAYO JARAMILLO en reciente artículo denominado "La obligación de lealtad dentro del periodo precontractual, con énfasis en los contratos de seguro y trasporte" ${ }^{\prime 12}$, en el cual lo primero que destaca es la discusión que existiría al respecto sobre si la responsabilidad en este caso debiera calificarse de contractual o de extracontractual ${ }^{13}$. Al respecto debemos decir que una apelación directa a la figura de la responsabilidad civil dentro de este contexto nos parece inadecuada, toda vez que cualquier análisis en este caso debe pasar primero por el tema del consentimiento y por la evaluación de los mecanismos de contratación, con la perspectiva precisamente de la formación de ese consentimiento, ya que es en principio inaceptable que un contratante, frente a cláusulas expresas y claras de un contrato, alegue la supuesta ignorancia de estas como fundamento de una mala fe precontractual de su cocontrante. Dentro del estudio que sigue, se verá las que constituyen a nuestra manera de ver las aproximaciones más válidas a este tema.

10 Cfr. a este respecto el importante estudio de J. E. NARVÁEZ: "Tratos preliminares y responsabilidad precontractual en la actividad aseguradora", Revista Latinoamericana de Seguros, n. ${ }^{\circ}$ 19, Bogotá, 2003, 125.

11 En este sentido José Fernando Torres. "Deberes de información en la etapa precontractual a cargo del asegurador y del candidato a tomador", Memorias del XXIII Encuentro Nacional de Acoldese, Cali, octubre de 2002, Bogotá, 2003, 80, expresa: "De otro lado, el incumplimiento del deber, si el contrato no se celebra, en principio no apareja perjuicios al asegurador, si bien cabe la posibilidad, de comprobarse que los hubo, de deducir responsabilidad del candidato a tomador, derivada de la norma general contenida en el artículo 863 C. Co., relativa a la buena fe de las partes en el periodo precontractual".

12 En Estudios de derecho civil. Obligaciones y contratos. Libro bomenaje a Fernando Hinestrosa, t. III, Bogotá, 2003, 429 y ss.

13 Este tópico también es abordado en el estudio de NarváEz. Ob. cit., 128. 


\section{Los vicios del consentimiento y particularmente el error}

En la teoría de los vicios del consentimiento se concreta el instrumento por excelencia para sancionar la violación a los deberes recíprocos de información entre las partes dentro de la teoría general del contrato, y particularmente en el campo del contrato de seguro es el instrumento que se utiliza sin duda alguna para sancionar las infracciones a ese deber cometidas por el asegurado. La regulación de nuestro artículo $1058 \mathrm{C}$. Co., se inscribe dentro de ese concepto al exigir que la llamada "reticencia o inexactitud en la declaración del estado del riesgo" por parte del tomador del seguro, para desencadenar un mecanismo sancionatorio, tenga la entidad suficiente de haber determinado la manifestación de voluntad del asegurador, a quien las verdaderas circunstancias del riesgo "hubieren retraído de celebrar el contrato, o inducido a estipular condiciones más onerosas".

Pero la preservación del deber de información del tomador frente al asegurado, como ya se ha dicho, mal podría lograrse a través de la teoría de los vicios del consentimiento, dado que la consecuencia de los mismos consiste normalmente en la destrucción de los efectos del contrato, respecto de la cual nadie podría estar más interesado que el asegurador mismo en la gran mayoría de los casos. En efecto, es sabido que tratándose del contrato de seguro es el asegurador el que normalmente está interesado en obtener una declaración de nulidad del contrato, que, en cambio, sólo podría interesar al tomador en el caso de no haberse producido un siniestro en lapso de vigencia del contrato y cuando pretendiera obtener la devolución de la prima pagada, un caso realmente poco frecuente en el desarro1lo de las relaciones asegurativas.

Por lo mismo, una primera dificultad que habría que enfrentar a este respecto sería la de identificar una infracción al deber de información del asegurador frente al tomador del seguro, que fuera susceptible de inducir en error trascendente la manifestación de voluntad del tomador; teniendo éxito frente a esta, la posibilidad de una acción de nulidad a favor del tomador se abriría sin duda con el objetivo anteriormente mencionado, y siempre y cuando no se hubiera producido siniestro dentro del lapso de vigencia del contrato. A este respecto son conocidos los debates doctrinarios que se han producido en torno a la aplicabilidad al contrato de seguro de los principios generales de los contratos en materia de vicios del consentimiento, no obstante la presencia de causales específicas de nulidad del contrato de seguro reguladas exhaustivamente en la ley, pero siempre en beneficio del asegurador; debates dentro de los cuales me ubico sin duda en el grupo que acepta la aplicación de los principios generales, sin perjuicio de la regulación especial de las causales que pudiéramos llamar propias del contrato de seguro.

Pero la segunda dificultad y la más difícil de sortear es la de establecer, a falta del interés en la acción de nulidad que es característico en la posición contractual del tomador del seguro, cuál es la sanción adecuada y jurídicamente posible 
que puede ser impuesta al asegurador por la falta cometida. Desde luego, ella no puede ser la nulidad del contrato cuando ha existido un siniestro y el tomador lo que precisa es que el contrato cumpla todos sus efectos y no que se le prive de ellos. En este sentido la teoría de los vicios del consentimiento no tiene ninguna utilidad práctica como preservadora de los deberes de información en el contrato de seguro.

\section{La teoría de las cláusulas abusivas referidas al deber de información}

a. Primer problema: la aplicabilidad al contrato

de seguro de la teoría de las cláusulas abusivas

La doctrina universal que se ha gestado alrededor del tema de las cláusulas abusivas nace a partir del momento en que las relaciones contractuales dejan de darse preponderamente dentro del esquema de que "dos personas, de idéntica situación jurídica y de igual poder económico, exponen y discuten en un libre debate sus pretensiones opuestas, se hacen concesiones recíprocas y acaban por celebrar un acuerdo cuyos términos han sido pesados y que en realidad constituye la expresión de su real voluntad"14. Por lo mismo el tema de las cláusulas abusivas se desarrolla en torno, primeramente, a los denominados contratos de adhesión y, posteriormente, a toda una serie de especies particulares de contratos denominados de distinta manera conforme a contenidos conceptuales no siempre coincidentes, tales como los contratos tipo, los contratos con condiciones generales, los contratos normativos y finalmente los contratos de consumo, caracterizados todos por la circunstancia de enfrentar a partes de fortaleza económica disímil y situación jurídica diferente, que no discuten en igualdad de condiciones sus pretensiones opuestas ni poseen un conocimiento similar sobre los bienes o servicios que constituyen el objeto del acuerdo, situación que las lleva a deferir las manifestaciones de voluntad a un contenido predispuesto por una de las partes, sobre el cual la otra tiene muy poca o ninguna capacidad de control.

Así sea verdad que no es estrictamente lo mismo hablar de un contrato de adhesión o de un contrato sometido a condiciones generales, que del derecho del consumo, es lo cierto que el contrato de seguro cae dentro de la tipicidad de los contratos de adhesión y al mismo tiempo cae dentro del ámbito del derecho del consumo. Lo primero porque sin duda la doctrina más generalizada reconoce que el contrato de seguro es un contrato de adhesión individualmente considerado, mirando la condición del tomador de seguro que se ve, en la inmensa mayoría de los casos, compelido a aceptar un clausulado predispuesto, la mayoría de las veces en formularios preimpresos, sobre cuyo contenido no tiene el menor control;

14 Corte Suprema de Justicia, Sala de Casación Civil. Sentencia del 12 de diciembre de 1936, XLV, 678 y 679. 
y lo segundo porque, desde el punto de vista del empresario asegurador, esos clausulados predispuestos están dirigidos a regular no una sino infinidad de relaciones que el mismo implementa con el público en general, público ajeno a cualquier tipo de calificación y profano en lo que se refiere a la sofisticación técnica y jurídica que está implícita en el contrato de seguro. Dentro de este contexto es entendido generalmente que el contrato de seguro se inscribe claramente dentro de las relaciones denominadas "de consumo"15.

No obstante, debe siempre tenerse en cuenta en materia de contratos de seguro algunas notas especiales que colocan a este contrato excepcionalmente en un lugar especial dentro del universo de los contratos de adhesión y de la relaciones de consumo, y que determinan a veces la necesidad de hacer consideraciones especiales: 1 . Respecto del contrato de seguro militan dos circunstancias que podemos llamar atenuantes de su carácter de contrato de adhesión: el extenso y creciente número de normas imperativas que lo rigen, y el control administrativo que existe sobre los modelos de pólizas y tarifas; 2 . La circunstancia innegable de que en algunos casos, raros por cierto, pero que se dan en la práctica, es el asegurado por su particular fortaleza económica o por la excepcionalidad de los riesgos cuya cobertura demanda, quien impone los términos del contrato y redacta algunas de sus cláusulas; 3 . La intervención de poderosos intermediarios, particularmente corredores de seguros dentro del proceso de negociación de algunos contratos de seguro como asesores del asegurado, puede impedir ciertamente que este pueda invocar defectos de información que podrían ser valederos para los demás asegurados en general, y 4 . No se debe desconocer el hecho de que existen opiniones dirigidas a considerar que el contrato de seguro, por ser un contrato de carácter aleatorio en el cual el asegurado tiene a su favor la expectativa de prestaciones económicas muy superiores a las que se generan a su cargo, no debe ser objeto indiscriminado de la regulación protectora característica para todos los consumidores.

A este último respecto vale la pena anotar, por una parte, que podría pensarse eventualmente que un contrato sometido a condiciones generales no requiere periodo de tratativas dentro del cual fuera necesaria la mutua información de los futuros contratantes ${ }^{16}$; por otra parte, que se encuentran ejemplos en legislaciones específicas de casos en los que se ha exceptuado el contrato de seguro de regímenes de protección a usuarios y consumidores corrientes; tal es el caso por ejemplo, en Francia, del artículo 1. ${ }^{\circ}$ del decreto del 24 de marzo de 1978, que se mencionará más adelante, dirigido a negar eficacia a cláusulas contractuales que

15 En este sentido se pronuncia sin duda entre nosotros, por ejemplo, Carlos I. JaramiLlo. "La protección del consumidor y sus principales manifestaciones en el derecho de seguros contemporáneo: Examen descriptivo", Memorias del VI Congreso Iberolatinoamericano de Derecho de Seguros. CILA 2000, Bogotá, 2000, 114.

16 NARVÁEZ, evoca esta circunstancia al mostrarse en desacuerdo con quienes sostienen que en los contratos sometidos a condiciones generales no existen tratativas: Ob. cit., 110. 
no estuvieren insertadas en el documento que suscribe el adherente, cuya aplicabilidad al contrato de seguro fue descartada por medio de una acción interpuesta por el gremio de aseguradores. En la legislación española, por su parte, se exceptúan de la regla general de imperatividad de las normas que regulan el contrato de seguro, los llamados "seguros contra daños por grandes riesgos" ${ }^{17}$.

b. Las cláusulas abusivas que tienen que ver con el derecho a la información

Es indudable que uno de los instrumentos a través de los cuales se preservan los deberes recíprocos de información es el de la teoría de las cláusulas abusivas, modernamente desarrollada a partir de ciertas normativas europeas que comenzaron a producirse no muy avanzado el siglo Xx y que han tenido robusto desarrollo y aplicación en el derecho continental europeo y comunitario a partir de finales de la década de los años setenta de ese siglo, ya que algunos de los criterios generalmente utilizados para identificar cláusulas abusivas tienen estrecha relación con la concepción que en general se tiene sobre los deberes de información de la parte predisponente. Veamos un inventario, no necesariamente taxativo, de normas que en distintos países proscriben la utilización de cierto tipo de cláusulas que, en cualquier contrato pero particularmente en contratos de adhesión, implican notoriamente falta a los deberes de información que están a cargo del predisponente:

- Las normas que descartan la validez de las condiciones generales del contrato, cuando no existe evidencia de que han sido sometidas a un proceso de negociación o aceptadas o conocidas expresamente por el adherente.

A nada distinto que a la más eficaz y creciente protección del derecho a la información de los adherentes, en el campo del derecho del consumo y de los contratos de masa, pueden atribuirse ciertos acercamientos de la teoría de las cláusulas abusivas, entre ellos uno de los más originales y primeros que consistió en sostener la inexistencia, la invalidez o al menos la inoponibilidad de las cláusulas de las condiciones generales de los contratos sometidos a ellas, en la medida en que no se acredite el conocimiento de las mismas por parte del adherente. A este género corresponde el conocido texto del artículo 1341 del Código italiano que expresa:

Condiciones generales del contrato. Las condiciones generales del contrato establecidas por uno de conclusión del contrato este las ha conocido o hubiera debido conocerlas usando la diligencia ordinaria. En todo caso no tendrán efecto si no fueren específicamente aprobadas por escrito las condiciones que establezcan, a favor del que las ha impuesto, limitaciones de responsabilidad, facultades de rescindir el contrato o suspender su ejecución, o sancionen a cargo del otro contratante caducidades, limi-

17 Párrafo $2 .^{\circ}$ artículo 44 de la Ley del Contrato de Seguros. 
taciones a la facultad de oponer excepciones con terceros, prórroga o renovación tácita del contrato, cláusulas compromisorias o derogaciones a la competencia de la autoridad judicial.

En el mismo sentido se orienta el "sistema acogido por la Directiva Europea 9313 CEE del Consejo de las Comunidades del 5 de abril de 1993 sobre cláusulas abusivas en los contratos celebrados con consumidores. En su artículo 3.1 establece la siguiente cláusula general: "Las cláusulas contractuales que no se hayan negociado individualmente se considerarán abusivas si, pese a las exigencias de la buena fe, causan en detrimento del consumidor un desequilibrio importante entre los derechos y obligaciones de las partes que se derivan del contrato"18.

Esta directiva ha sido incluida con carácter indicativo por la ley del $1 .^{\circ}$ de febrero de 1995 en Francia, por ejemplo ${ }^{19}$.

- Normas que niegan validez a condiciones que no figuren en el documento que firma el adherente, comúnmente conocidas como cláusulas de reenvío.

También se dirigen a preservar el deber de información de los empresarios profesionales frente a sus contratantes las normas que consagran idénticas sanciones para las cláusulas o condiciones del contrato que no figuren en el documento que suscribe el adherente. En ambos casos, la teoría de las cláusulas abusivas, en el ámbito de los contratos de adhesión, provee de un mecanismo expedito y de fácil juzgamiento para eventos en los que se considera claramente afectado a un contratante que no fue adecuadamente informado, en este caso de condiciones que rigen el desarrollo de la relación contractual. A este género de normas pertenece sin duda el artículo 3. ${ }^{\circ}$ de la ley del 8 de octubre de 1980 española, que expresa: "Las condiciones generales, que en ningún caso podrán tener carácter lesivo para los asegurados, habrán de incluirse por el asegurador en la proposición del seguro si la hubiere y necesariamente en la póliza de contrato o en un documento complementario que se suscribirá por el asegurado y al que se entregará copia del mismo".

Este es igualmente el caso del artículo 1. ${ }^{\circ}$ del decreto del 24 de marzo de 1978 en Francia; si bien el mismo no es aplicable ya en el derecho positivo francés, es un buen ejemplo de un esfuerzo por proteger de una manera muy eficaz el derecho a la información ${ }^{20}$.

Por su parte, el artículo $10 .^{\circ}$, aparte $1 .^{\circ}$ letra a) de la Ley General para la Defensa de los Consumidores y Usuarios de España, exige "concreción, claridad y sencillez en la redacción, con posibilidad de comprensión directa, sin reenvíos a textos o documentos que no se faciliten previa o simultáneamente a la conclu-

18 J. Llobet i Aguado. El deber de información en la formación de los contratos, Madrid, Marcial Pons, 1996, 90 y 91.

19 Villegas. Ob. cit., 44.

20 L. Villegas. Le clauses abusives dans le contrat dássurance, Aix en Provence, 1998, 42 y 43. 
sión del contrato, y a los que, en todo caso, deberá hacerse referencia expresa en el documento contractual".

- Las disposiciones legislativas que prescriben la inexistencia de las cláusulas sorprendentes o inusuales en los contratos de adhesión o con condiciones generales, tales como la ley alemana del 9 de diciembre de 1976, o la modificación introducida al artículo 864 del Código austriaco en $1979^{21}$.

- Las que condicionan la validez de las condiciones generales del contrato a la aprobación por autoridad, como ocurre con la ley holandesa ${ }^{22}$.

- Las que sancionan expresamente con nulidad del contrato o de cláusulas contractuales específicas ante el incumplimiento genérico de los deberes de información por parte del oferente.

Es el caso muy singular por cierto del artículo 37 de la Ley de Defensa del Consumidor en Argentina (24.240 de 1993), que en su inciso 3. ${ }^{\circ}$ expresa: "En caso que el oferente viole el deber de buena fe en la etapa previa a la conclusión del contrato o en su celebración o transgreda el deber de información o la legislación de defensa de la competencia o de lealtad comercial, el consumidor tendrá derecho a demandar la nulidad del contrato o la de una o más cláusulas".

Es el caso también de nuestro proyecto de estatuto del consumidor que, como veremos más adelante, condiciona la validez de los contratos de adhesión (art. 35), entre otros, a la información suficiente, anticipada y expresa al adherente sobre la existencia, efectos y alcances de las condiciones generales.

- Dentro de este inventario, debe incluirse la alusión a modernos planteamientos legislativos y doctrinarios, dirigidos en dos sentidos: a establecer la supremacía por vía general de las normas dispositivas de la ley sobre las condiciones generales de los contratos, y a dar, igualmente por vía general, carácter imperativo a todas las normas legales regulatorias del contrato, con excepción de las que sean más favorables al tomador del seguro. Es indudable que en este caso se fortalece el derecho a la información del tomador de manera indirecta pero muy efectiva, al remitir casi en su totalidad la disciplina del contrato a la regulación legal, cuyo conocimiento por parte de los usuarios y consumidores es mucho más fácil y directo, a la vez que presumiblemente menos proclive a establecer ventajas a favor de cualquiera de las partes.

Respecto del primer planteamiento, ha sido destacado por el profesor JORGE MOSSET ITURRASPE ${ }^{23}$ como producto de la doctrina que se ha desarrollado a partir

21 "Las cláusulas inesperadas contenidas en las condiciones generales de los contratos o en los contratos tipo utilizados por una de las partes, serán nulas cuando desfavorezcan a la otra parte, en la medida en que esa parte legítimamente en función de las circunstancias, y particularmente en función de la presentación del formulario, pueda haber ignorado la existencia de dichas cláusulas, a menos que su contratante le haya llamado especialmente la atención sobre ellas".

22 Citada por Escobar Sanín. Ob. cit., 336.

23 J. Mosset Iturraspe. "Las cláusulas abusivas en la contratación contemporánea", Memorias XXIII Encuentro Nacional de Acoldese, Cali, 2002, Bogotá, 2003, 40. 
de la expedición en 1993 de la ley de defensa del consumidor en Argentina, para darle contenido a la norma que da por no convenidas las cláusulas que "desnaturalicen las obligaciones" o que "importen restricción o renuncia de los derechos del consumidor o amplíen los derechos de la otra parte" (art. 37 Ley 24.240 de 1993). Respecto del segundo, se consagra en el artículo 2. ${ }^{\circ}$ de la ley española de seguros de 1980, conforme a la cual: "Las distintas modalidades del Contrato de Seguro, en defecto de ley que le sea aplicable, se regirán por la presente ley, cuyos preceptos tienen carácter imperativo, a no ser que en ellos se disponga otra cosa. No obstante se entenderán válidas las cláusulas contractuales que sean más beneficiosas para el asegurado".

\section{B. Mecanismos particulares de protección al derecho a la información del tomador, utilizados en legislaciones extranjeras}

Vale la pena mencionar, a título de ejemplo, algunos mecanismos particulares de protección al derecho a la información que se utilizan respecto del contrato de seguro, en otras legislaciones.

1. Le ley española que prohíbe la posibilidad de imponer sanciones al asegurado por inexactitud o reticencia en la declaración del estado del riesgo, en aquellos caso en que el asegurador no le ha provisto de un formulario. En efecto: el artículo $10{ }^{\circ}$ de la ley española de seguros, modificado en este punto por la Ley 21 del 19 de diciembre de 1990, establece: "El tomador del seguro tiene el deber, antes de la conclusión del contrato, de declarar al asegurador, de acuerdo con el cuestionario que este le someta, todas las circunstancias por él conocidas que puedan influir en la valoración del riesgo. Quedará exonerado de tal deber si el asegurador no le somete cuestionario o cuando, aun sometiéndoselo, se trate de circunstancias que puedan influir en la valoración del riesgo y que no estén comprendidas en él".

Curiosamente, una decisión de la Sala Civil de la Corte Suprema de Justicia colombiana, que resulta criticable porque es contraria al marco normativo existente en Colombia, crítica en que nos identificamos con JorGE EDUARDO NARVÁEZ ${ }^{24}$, llegó a una conclusión semejante cuando afirmó: "Ahora es posible la contratación sin ninguna información sobre el estado del riesgo, porque no hubo declaración alguna, ni tampoco inspección, caso en el cual debe entenderse la manifestación tácita de la aseguradora de asumir el riesgo cualquiera que sea la probabilidad del daño que gravite sobre el interés asegurado. En otras palabras, en tal evento no se puede predicar nulidad por reticencia, ni mucho menos por inexactitud, ni tampoco es posible la reducción de la prestación a cargo del asegurador ${ }^{\prime \prime 2}$.

24 NarváEZ. Ob. cit., 126.

25 Corte Suprema de Justicia, Sala Civil. Sentencia del 19 de mayo de 1999, exp. 4923, M. P.: José Fernando Ramírez. 
2. Las normas que protegen al tomador frente a las divergencias que puedan existir entre el texto expedido de la póliza de seguro y los términos del ofrecimiento recibido del asegurador; entre estas se pueden citar como ejemplos: a. El mecanismo consagrado en el artículo $8 .^{\circ}$ de la ley española de 1980 sobre el contrato de seguro, que permite al tomador declarar dentro de un tiempo prudencial, subsiguiente a aquel en que ha recibido la póliza de seguro, por las divergencias que pueda presentar el texto de la misma con la proposición inicial del asegurador. b. El artículo 12 de la Ley 17.418 de Argentina, que establece un mecanismo similar, pero condicionando la aceptación tácita del tomador a que se le haya hecho advertencia previa de ese derecho, mediante "cláusula inserta en forma destacada en el anverso de la póliza"26.

3. Las exigencias concretas de determinado tipo de informaciones que las aseguradoras deben suministrar a sus asegurados so pena de incurrir en infracciones generadoras de responsabilidades administrativas. Rubro dentro del cual pueden ubicarse las disposiciones contenidas en los artículos 53, 60 y 81 de la ley española de ordenación y supervisión de los seguros privados de $1995^{27}$.

4. El artículo 112-2 del Código de Seguros de Francia, emanado de la Ley 891014 de 1989, establece la obligación para el asegurador de proporcionar al tomador del seguro, antes de la celebración del contrato, una ficha de información, un ejemplar del proyecto de contrato y de las piezas anexas; posteriormente, una ley de enero de 1994 estableció algunas precisiones al respecto, de las cuales resulta un cúmulo de informaciones bastante voluminoso que incluye igualmente instrucciones o "modalidades de examen de las reclamaciones" que el asegurado puede llegar a presentar e indicación de la ley aplicable al contrato. El profesor JEAN BIGOT ${ }^{28}$ hace una extensa crítica a estas disposiciones, que aparentemente no son claras en cuanto a las sanciones que el asegurador puede esperar de las omisiones que cometa a este respecto, pero claramente señalan una manera de preservar el deber de información del asegurador.

5. También en orden a castigar al asegurador que no orienta adecuadamente a su asegurado en el momento de suministrar información sobre el estado del riesgo,

26 Un análisis crítico muy detallado de esta disposición en la legislación argentina se encuentra en Stiglitz, Ob. cit., 415 y ss.

27 Particularmente destacado, el artículo 60 señala: "1.- Antes de celebrar un contrato de seguro distinto al seguro de vida, si el tomador es una persona física, o cualquier contrato de seguro de vida, la entidad aseguradora deberá informar al tomador sobre la legislación aplicable al contrato, sobre las disposiciones relativas a las reclamaciones que puedan formularse y sobre los demás extremos que se determinen reglamentariamente. 2.- Durante todo el periodo de vigencia del contrato de seguro sobre la vida, la entidad aseguradora deberá informar al tomador de las modificaciones de la información inicialmente suministrada, y asimismo, en los términos que reglamentariamente se determinen, en todo caso con periodicidad anual, sobre la situación de su participación en beneficios": en E. Caballero SÁnChEZ. El consumidor de seguros: protección y defensa, Madrid, $1997,69$.

28 J. Bigot. Traité du droit d'assurannces, t. III: "Le contrat dássurance", Paris, 2002, 462 a 464. 
el Código de Seguros francés (inc. 2. ${ }^{\circ}$ art. 112-3) ha impuesto al asegurador la carga de probar que las preguntas que ha hecho al respecto al asegurado han sido formuladas de manera clara y precisa; en caso contrario no se podría valer de una respuesta evasiva, vaga o incompleta para impugnar la validez del contrato ${ }^{29}$.

6. Finalmente, vale la pena mencionar, como mecanismo muy interesante dirigido a finalidad similar, la concesión de los derechos de reflexión y arrepentimiento a los asegurados, una vez celebrado el contrato, al cual se refiere CARLOS IGNACIO JARAMILLO, así: "En virtud del supraindicado derecho, el asegurado cuenta con un término prudencial, a fin de evaluar $y$, por ende, reflexionar acerca de la información suministrada por el predisponente, incluso con posterioridad a la celebración formal del contrato -en ciertos sistemas- lo que explica que en ellos, por lo menos de hecho, no quede definitivamente consolidado hasta tanto él expire, v. gr. en los países de la Comunidad Europea, en desarrollo de la tercera directiva de 1992, relativa al seguro de vida". Este derecho ha sido incorporado igualmente en la ley española de 1995 (art. 83 a) y a la ley belga en $1992^{30}$.

\section{Mecanismos consagrados en Colombia, a fin de preservar el derecho a la información por parte del tomador del seguro}

Es indudable que aunque no exista una norma expresa al respecto en el Código colombiano, en el que brilla por su ausencia ${ }^{31}$, el asegurador, como todo contratante y, con mayor razón, como todo contratante empresario dentro de un contrato de adhesión, tiene también la obligación de suministrar a su clientela cierto tipo de información relativa, en este caso, al servicio que provee a través del contrato de seguro. Lo realmente complejo es determinar cuál es la naturaleza y la profundidad de esa información, y cuál puede ser la sanción derivada del incumplimiento del asegurador a este respecto, sobre todo en una legislación como la nuestra desprovista, se repite, de una regulación expresa de la materia.

Es cierto que existen dos instrumentos al menos indirectos mediante los cuales la ley se ocupa de este tema. Uno es precisamente el que ya se ha analizado, conforme al cual el asegurador que orienta la declaración de asegurabilidad del tomador por medio de un cuestionario, se ve beneficiado frente a aquel que no lo

29 Ibíd., 469

30 JaRAmillo. "La protección del consumidor y sus principales manifestaciones en el derecho de seguros contemporáneo", en cit., 120.

31 No obstante, debe registrarse en el estatuto de contratación administrativa la disposición contenida en su artículo 97, que aunque general para todas las empresas vigiladas por la Superintendencia Bancaria y sin un instrumento claro de sanción en caso de incumplimiento, revela al menos una preocupación de principio sobre el tema y expresa: "Información a los usuarios. Las entidades vigiladas deben suministrar a los usuarios de los servicios que prestan la información necesaria para lograr la mayor trasparencia en las operaciones que realicen, de suerte que les permita, a través de elementos de juicio claros y objetivos, escoger las mejores opciones del mercado". 
hace. Hay aquí un castigo que se traduce en aumento efectivo de la carga probatoria para el asegurador que, al no someter un cuestionario a su tomador, omite informarlo sobre las circunstancias que a su juicio pueden influir mayormente en su concepción acerca del estado del riesgo. Otro es el que se concreta a través de todas las normas de derecho público de seguros que imponen al asegurador la carga, so pena de graves sanciones administrativas, de ceñirse a ciertos requisitos formales en la expedición de las pólizas de seguro, en cuanto muchas de ellas tienden a que el asegurado conozca bien o no pueda ignorar ciertos efectos o condiciones técnicas o jurídicas del contrato que resultan particularmente relevantes ${ }^{32}$.

Ya hemos visto que en otras legislaciones ese castigo va más allá, hasta el punto de impedir al asegurador alegar la existencia de inexactitud o reticencia en la declaración del estado del riesgo, si no ha propuesto un formulario, esto es, si no ha orientado la declaración del tomador en torno a la información que debe proporcionar.

Otra forma, quizás la más eficaz y difundida de obligar al asegurador a proporcionar adecuada información a su clientela, sobre ciertos aspectos del contrato y del servicio implícito en él, se traduce en una regulación severa de la eficacia de las condiciones generales del contrato dentro del contexto de los contratos de adhesión, condicionando esa eficacia a ciertos requerimientos de publicidad o de información expresa y previa al adherente. Una tendencia que sin duda, como se ha visto, se ha convertido ya en una realidad incuestionable en los modernos Códigos mercantiles y particularmente frente a los derechos del consumidor, pero que en Colombia espera todavía consagración efectiva y expresa.

\section{Mecanismos normativos de carácter general}

La Constitución Nacional se refiere al derecho a la información en su artículo 78, que fue citado al inicio de este estudio.

Por su parte, normas generales del Estatuto Orgánico del Sistema Financiero hacen lo propio, al establecer obligaciones específicas para las entidades vigiladas por la Superintendencia Bancaria, en torno a la publicidad que dirigen al público y a la información que están obligas a suministrar a su clientela.

Así pues, el artículo 97 del Estatuto Orgánico, dispone:

Información a los usuarios. Las entidades vigiladas deben suministrar a los usuarios de los servicios que prestan la información necesaria para lograr la mayor transparencia en

32 En Colombia, son particularmente notorias las normas que exigen redactar las pólizas con caracteres tipográficos visibles, incluir en las primeras páginas las cláusulas correspondientes a la identificación del riesgo, o la que obliga a señalar en la carátula de las pólizas, también con caracteres tipográficos visibles, la condición de terminación automática del contrato por mora en el pago de la prima. 
las operaciones que realicen, de suerte que les permita, a través de elementos de juicio claros y objetivos, escoger las mejores opciones del mercado.

El artículo 99, por su parte, impone la necesidad de autorización previa de la Superintendencia para todo programa publicitario de las entidades vigiladas, con el fin de que ellos se ajusten a las normas vigentes, a la realidad jurídica y económica del servicio promovido y para prevenir actos de competencia desleal.

Concretamente en lo que se refiere al contrato de seguro, el artículo $100 \mathrm{del}$ Estatuto, bajo el título de "Régimen de protección a tomadores de seguro y asegurados", establece directrices concretas para salvaguardar la libertad de éstos para decidir la contratación de seguros y escoger aseguradoras e intermediarios, para lo cual es requisito previo necesario el de la adecuada información.

Estos mecanismos, sin embargo, no se reflejan de una manera directa en la realidad jurídica del contrato, individualmente considerado, sino que son fuente generadora de responsabilidades administrativas para las entidades.

\section{Normas jurídicas que se refieren específicamente en Colombia}

al derecho a la información en el contrato de seguro

a. Las condiciones generales del contrato

En Colombia resulta notable registrar, en el ámbito de la regulación del contrato de seguro, que el artículo 7. ${ }^{\circ}$ de la Ley 27 de 1888 estipuló, en una época tan alejada en el tiempo, que "[1]as condiciones generales que para los contratos establezcan las compañías de seguros se considerarán estipulaciones obligatorias para ambas partes contratantes, aun cuando no se hallen detalladas en las pólizas, siempre que en ellas declaren los contratantes que les son conocidas y que se someten a ellas" ${ }^{\prime \prime 3}$.

Desde el punto de vista legislativo es pertinente anotar que antes de que con la Ley 45 de 1990 se introdujera una modificación sustancial del sistema de vigilancia y control de la actividad aseguradora, que pasó del sistema de control denominado "de pólizas y tarifas" al sistema de control "por márgenes de solvencia", los modelos de las pólizas de seguro que las compañías utilizaban en el mercado estaban sometidas a una probación de carácter previo por parte de la Superintendencia Bancaria y que, dentro de este contexto, el parágrafo del artículo 1047 C. Co. estipulaba: "Se tendrán como condiciones generales del contrato, aunque no hayan sido consignadas por escrito, las aprobadas por la autoridad competente para el respectivo asegurador en relación con el seguro pactado, salvo las relativas a riesgos no asumidos". 
Esta norma del Código de Comercio le dio un valor excesivo a un control que solamente tiene carácter administrativo y que, como se sabe, la Superintendencia Bancaria raramente ha ejercido con suficiente severidad y para fines distintos a los de simple legalidad o conformidad con las normas imperativas del Código, proveyendo de firmeza y obligatoriedad por vía general a las condiciones generales del contrato, sin base real, pues debe insistirse en que ese control de carácter administrativo no ha sido tomado nunca muy en serio entre nosotros $y$, particularmente, no se ha utilizado para propender eficazmente por la protección del público consumidor.

En vigencia la Ley 45 de 1990, este parágrafo del artículo 1047 dejó de tener una vigencia práctica, toda vez que a partir de entonces no se podía hablar realmente de condiciones aprobadas por la autoridad competente, en la medida que el control de pólizas y tarifas perdió importancia y pasó a ser un control a posteriori que simplemente faculta a la Superintendencia para hacer observaciones y glosas, y para prohibir eventualmente el uso de ciertas pólizas o cláusulas en casos extremos, pero sin que se parta de la base de un acto de aprobación. Lo que la Ley 45 estatuyó fue el deber de las compañías de depositar ante la Superintendencia los modelos de las pólizas, para efectos del control posterior.

Solamente la Ley 389 de 1997 vino a modificar el parágrafo del artículo 1047 que reza hoy: "En los casos en que no aparezca expresamente acordadas, se tendrán como condiciones del contrato, aquellas de la póliza o anexo que el asegurador haya depositado en la Superintendencia Bancaria para el mismo ramo, amparo, modalidad del contrato y tipo de riesgo". Lo cual, desde luego, aleja aún más la regulación positiva del contrato de seguro entre nosotros de lo que debe ser un prohijamiento adecuado del derecho del asegurado a la información, porque vuelve a dar un espaldarazo de validez a las condiciones generales del contrato de seguro impuestas por el asegurador, con el solo requerimiento del depósito de los modelos de pólizas en las dependencias de la Superbancaria, ahora sin que medie siquiera el acto de aprobación que antes existía y era necesario para que las compañía pudieran explotar sus productos frente al público.

b. Las normas del Código de Comercio y del Estatuto Orgánico del Sistema Financiero que se relacionan con el derecho a la información del asegurado

Son realmente muy pocas las normas jurídicas que están dirigidas expresamente a preservar el derecho a la información por parte del tomador del seguro en la legislación colombiana. En el texto original del Código de Comercio pueden ser identificadas como tales los artículos 1046, 1047 y 1048; el primero de ellos, con su texto modificado por la Ley 389 de 1997, ordena al asegurador entregar el original de la póliza de seguro al tomador dentro de los 15 días siguientes a la fecha de celebración del contrato y dispone que la misma deberá redactarse en castellano, facultando excepcionalmente a la Superintendencia Bancaria para 
señalar los ramos y la clase de contratos que pueden ser redactados en idioma extranjero.

El artículo 1047 señala las menciones que deben estar contenidas en la póliza de seguro, además de las condiciones generales, y en su parágrafo establece la ya comentada disposición atinente a que, cuando no aparezcan expresamente acordadas, se tendrán como condiciones del contrato las del modelo depositado por el asegurador en la Superintendencia Bancaria.

El artículo 1048, por su parte, ordena tener como parte integrante de la póliza la solicitud de seguro suscrita por el tomador y los anexos que se expidan para adicionar, modificar, suspender, renovar o revocar la póliza. El parágrafo de este artículo así como el parágrafo del artículo 1046 establecen importantes disposiciones en torno a la obligación que el asegurador tiene de expedir duplicados o copias, a petición del tomador, del asegurado o del beneficiario, de la póliza misma, de la solicitud de seguro y de sus anexos, así como de los documentos que den fe de la inspección del riesgo.

El Estatuto Orgánico del Sistema Financiero, por su parte, en el numeral 2 de su artículo 184, establece que las pólizas deben redactarse de tal forma que sean de fácil comprensión para el asegurado: por tanto, conforme a la misma norma, los caracteres tipográficos deben ser fácilmente legibles, y los amparos básicos y las exclusiones deben figurar en caracteres destacados en la primera página de la póliza.

A estas normas puede agregarse la disposición contenida en el inciso $2 .^{\circ}$ artículo 1068 C. Co. que ordena consignar con caracteres destacados en la carátula de la póliza el efecto de terminación automática del contrato que para el contrato de seguro de daños tiene la mora en el pago de la prima, a partir de la reforma que se hizo a este respecto en la Ley 45 de 1990.

Estas disposiciones que consagran requisitos formales, a veces un tanto ingenuos para las pólizas de seguro, revelan desde luego un interés de la ley en preservar al máximo el derecho a la información de los tomadores del seguro, sobre los aspectos más relevantes del contrato. Debe destacarse que la observancia de estos requerimientos formales tiene, al menos teóricamente, una sanción muy grave desde el punto de vista de la disciplina del contrato, que quizás no ha sido suficientemente observada, cuando el literal a artículo 184 del Estatuto dispone refiriéndose al contenido de las pólizas de seguro: "Su contenido debe ceñirse a las normas que regulan el contrato de seguro y a las demás disposiciones imperativas que resulten aplicables, so pena de ineficacia de la estipulación respectiva".

Quiere esto decir que, a más de las sanciones de carácter administrativo que están señaladas en el numeral 4 del mismo artículo 184, que van desde la prohibición de la utilización de la póliza correspondiente hasta la suspensión del certificado de autorización de la aseguradora (incluso la revocación del certificado al tenor de lo dispuesto por el num. 3 art. 100 ibíd.), las omisiones a este respecto generan la ineficacia de las cláusulas respecto de las cuales se haya cometido la 
infracción. Este dispositivo podría llegar a ser muy efectivo para proteger al tomador, en el caso de cláusulas redactadas en idioma extranjero, o de difícil comprensión, o si se trata de las que contienen la identificación de los riesgos asegurados, si no figuran en la primera página de la póliza, etc.

c. Normas jurídicas en torno a las cláusulas abusivas, con referencia a los deberes recíprocos de información

En Colombia, como es bien sabido, no existen todavía desarrollos concretos en el plano legislativo, salvo los de la Ley 142 de 1994 en torno a las cláusulas abusivas, y solamente ahora, cuando es predecible la adopción a mayor o menor plazo de un nuevo estatuto del consumidor en el cual seguramente veremos copiadas algunas de las experiencias europeas y comunitaria en esta materia, podremos estar seguros de encontrar finalmente la consagración apropiada por lo menos de algunos de estos mecanismos.

\section{La jurisprudencia colombiana}

a. La jurisprudencia colombiana sobre cláusulas abusivas

Por su parte, nuestra jurisprudencia ha sido a este respecto bastante conservadora, no obstante que ya en el lenguaje común de las providencias judiciales no faltan las frecuentes alusiones a las cláusulas abusivas o al abuso de la posición dominante $^{34}$. Un examen exhaustivo de esas decisiones, sin embargo, demuestra con claridad que si bien se encuentran generalmente reconocida la figura del abuso del derecho como fuente de obligaciones indemnizatorias en multitud de circunstancias e identificadas sus características básicas, el reconocimiento de casos de declaratoria de ineficacia de cláusulas contractuales derivada del hecho de su calificación como cláusulas abusivas como motivo autónomo de dicha declaración es realmente excepcional y raro, y es francamente inexistente un caso identificable de calificación de cláusulas abusivas por omisiones al deber de información de cualquiera de las partes.

Podríamos afirmar que en lo que se refiere a la jurisprudencia de la Sala Civil de la Corte, muchas veces se ha confundido, con la aplicación de teorías acerca de las cláusulas abusivas, lo que han sido simplemente conclusiones relativas a la ineficacia de ciertas cláusulas contractuales por ser contrarias a normas imperati-

34 Sobre la jurisprudencia colombiana en esta materia, resulta muy ilustrativo E. RENGIFO García. Del abuso del derecho al abuso de la posición dominante, Bogotá, 2002, en donde se hace un detenido recuento de los fallos de nuestras Corte Suprema de Justicia y Corte Constitucional que se han referido en general al tema del abuso del derecho y a las cláusulas abusivas. 
vas (ilegalidad), o por constituir indebidas limitaciones a la responsabilidad de alguno de los contratantes, situación que cae en la mayoría de los casos en el supuesto anterior de ilegalidad por contravenir la prohibición generalmente establecida de exonerar el dolo futuro o la culpa grave por asimilación a aquel, o por ser ambiguas en su contenido.

Debe destacarse no obstante la sentencia del 2 de febrero de 2001, expediente 5670 , a la cual pertenecen los siguientes apartes:

Cumple anotar que tratándose de negocios jurídicos concluidos y desarrollados a través de la adhesión a condiciones generales de contratación, como-por regla-sucede con el de seguro, la legislación comparada y la doctrina universal, de tiempo atrás, han situado en primer plano la necesidad de delimitar su contenido, particularmente para "excluir aquellas cláusulas que sirven para proporcionar ventajas egoístas a costa del contratante individual" (LUKES).

Con tal propósito, por vía de ejemplo, se promulgaron normas por la Comunidad Europea (Directiva 93/13 del 5 de abril de 1993 sobre cláusulas abusivas en los contratos celebrados entre profesionales y consumidores), que también se encuentran incorporadas, a nivel interno, en los derechos alemán (Ley de 9 de dic. de 1976), luxemburgués (Ley 25 de 1983), italiano (arts. 1469 bis y ss. C. C.), francés (Ley 95 de 1996), español (Ley 7. a de 1998) y, en similar sentido -además-, en las legislaciones brasileña (art. 51 CDC), paraguaya (art. 691 C. C.), argentina (art. 37 Ley 24.240 y Dcto. 1798 de 1994), e igualmente en la colombiana, circunscrita ésta a los contratos de prestación de un servicio público (art. 133 Ley 142 de 1994), legislaciones en las cuales, de ordinario, se advierten como características arquetípicas de las cláusulas abusivas - primordialmente-: a) que su negociación no haya sido individual ${ }_{i}$ b) que lesionen los requerimientos emergentes de la buena fe negocial -vale decir, que se quebrante este postulado rector desde una perspectiva objetiva: buena fe, probidad o lealtad-, y c) que genere un desequilibrio significativo de cara a los derechos y las obligaciones que contraen las partes $[\ldots]$

[L]o abusivo -o despótico- de este tipo de cláusulas - que pueden estar presentes en cualquier contrato y no sólo en los de adhesión o negocios tipo-, se acentúa aún más si se tiene en cuenta que el asegurador las inserta dentro de las condiciones generales del contrato (art. 1047 C. Co.), esto es, en aquellas disposiciones -de naturaleza volitiva y por tanto negocial- a las que se adhiere el tomador sin posibilidad real o efectiva de controvertirlas, en la medida en que han sido prediseñadas unilateralmente por la entidad aseguradora, sin dejar espacio - por regla general- para su negociación individual.

Esta sentencia, no obstante la extensa referencia al tema de las cláusulas abusivas, a la larga se limitó a descartar la validez de una cláusula inserta en un seguro de cumplimiento, conforme a la cual el tomador habría de demostrar la ocurrencia del siniestro con una sentencia judicial que declarara el incumplimiento del contrato garantizado, en razón de violar dicha cláusula una norma imperativa de la 
ley, en este caso el artículo 1080 C. Co., que a juicio de la Corte autoriza al beneficiario del seguro a demostrar la ocurrencia del siniestro extrajudicialmente. Habría que agregar que milita también en el mismo sentido el hecho de que el artículo 1077 del mismo estatuto, al consagrar las cargas probatorias que tiene el asegurado en caso de siniestro, no limita los medios de prueba a este respecto, y tratándose de una norma de carácter procesal puede afirmarse igual carácter imperativo a esa disposición. Por lo mismo, esta sentencia, independientemente de su importancia como referencia al tema de las cláusulas abusivas, no es un antecedente que pueda ser registrado como avance jurisprudencial en esta materia.

Cabe agregar que, como se indicará más adelante, la sentencia anterior fue reiterada extensamente, en cuanto a sus planteamientos generales, por la del 13 de diciembre de 2002, con ponencia del mismo magistrado CARLOS I. JARAMILLO (exp. 6462), sentencia esta última que hizo referencia al tema con la perspectiva de las cláusulas limitativas o exonerativas de responsabilidad que en el caso se habían incorporado a un contrato de leasing. Igualmente lo fue en sentencia del 20 de septiembre de 2002 (exp. 4799) de la misma Sala, que se citará también más adelante, por tratar el tema específico de las garantías y la relación que éstas deben tener con el riesgo asegurado, pero que concluye dando las razones por las cuales, en el caso, se consideró que no era abusiva una cláusula que establecía cierto tipo de garantía.

Por lo demás, debe admitirse que las decisiones jurisprudenciales en Colombia han ido muy poco más allá de la aplicación de las normas usuales de interpretación de los contratos respecto de las cláusulas ambiguas, e incluso de vez en cuando y también recientemente se dan casos de reiteración a ultranza del valor normativo del contrato aun refiriéndose a los de adhesión y en presencia de cláusulas muy desventajosas para el adherente. En sentencia del 21 de mayo de 2002 por ejemplo, al confirmar la validez de la cláusula que en un contrato de seguro excluía la pertinencia del amparo en el caso en que el vehículo no hubiera sido importado legalmente al país, no obstante el asegurado ajeno al trámite de importación, se sostuvo con firmeza que ni la equidad ni la buena fe podrían servir para negar validez a cláusulas lícitas del contrato de seguro ${ }^{35}$.

Un recuento detenido de las decisiones de la Sala Civil a este respecto, permite apreciar cierta consistencia en decisiones en torno al tema de cláusulas limitativas de responsabilidad (12 de diciembre de 1936, M. P.: EDUARDO ZulETA ÁnGel, XLIV, 674 y ss. 6 de marzo de 1972, M. P.: Humberto MurCia Ballén, CXLII, 98 y ss.; 13 de diciembre de 2002, M. P.:; Carlos IgnaCiO Jaramillo) ${ }^{36}{ }_{;}$cláusulas

35 Sentencia del 21 de mayo de 2002, extractos en Jurisprudencia y Doctrina, julio de 2002, xxXI.

36 Esta última sentencia es particularmente importante en la medida en que reitera extensamente la de fecha 2 de febrero de 2001 en torno a sus planteamientos generales respecto de las cláusulas abusivas y hace precisiones importantes sobre el tema de las 
ambiguas (15 de diciembre de 1970, CXXXVI; 19 de agosto de 1980, CLXVI); invalidez de cláusulas que señalan aumentan o disminuyen los términos de prescripción señalados por la ley; invalidez de cláusulas que modifican las reglas sobre carga de la prueba, estos dos últimos casos que pueden inscribirse dentro del supuesto también ampliamente admitido como simple desarrollo de normas legales expresas, de invalidez o nulidad de cláusulas que contravienen normas jurídicas de carácter imperativo.

No se incluye a este respecto una referencia directa a la conocida sentencia de la Sala de Casación Civil de la Corte Suprema de Justicia del 19 de octubre de 1994, toda vez que se trata de un antecedente que a nuestro juicio no está relacionado con el tema de las cláusulas abusivas y su ineficacia eventual, sino con el tema del "abuso de la posición dominante" como fuente de una obligación resarcitoria o indemnizatoria.

Un avance a nuestro juicio más importantes que los anteriores, se ha dado recientemente en laudo arbitral del 11 de octubre de $2001^{37}$, en el cual se declaró inaplicable una cláusula contractual que establecía una carga probatoria excepcional al asegurado para que pudiera configurarse la cobertura en una póliza de seguro de riesgos financieros, afirmándose allí que de mantenerse una exigencia como esa se configuraría una "falta de reciprocidad esencial" en el contrato. A este laudo corresponden los siguientes apartes:

El Tribunal es consciente de que en la "Condición Especial" primera (1. $\left.{ }^{\mathrm{a}}\right)$ de la condición 1.1 de la póliza, se limita el cubrimiento de infidelidad de empleados en lo concerniente a préstamos u operaciones comerciales a los casos de actos deshonestos o fraudulentos "... cometidos por un empleado que obtenga una ganancia financiera personal ilícita proveniente de tales acciones", pero considera que una exigencia probatoria de este tipo para el asegurado, con miras a la demostración de la ocurrencia del siniestro, además de los demás elementos que lo estructuran conforme a la definición básica, comporta un desequilibrio contractual evidente que podría llevar a hacer nugatoria la reciprocidad esencial del contrato cuando se trata de siniestros dentro de circunstancias de actos deshonestos o fraudulentos cometidos en desarrollo de "préstamos u operaciones comerciales", que hacen inaplicable esta condición dentro del contexto de unas condiciones que son dictadas y redactadas por el asegurador. En efecto, la prueba de la obtención efectiva, no solamente de la intención, en cuanto a la ganancia financiera personal ilícita suele ser imposible, y en ello le asiste razón a la convocante, porque muchas veces la ganancia permanece fácilmente oculta al escrutinio de la investigación o porque incluso puede no llegarse a realizar efectivamente por circunstancias ajenas al autor. Por lo mismo en este caso, esta sería una razón

cláusulas limitativas o exonerativas de responsabilidad y los casos en que las mismas pueden considerarse prohibidas.

37 Dentro del proceso arbitral de Andino Capital Markets S. A. Comisionistas de Bolsa en liquidación contra Interamericana de Seguros S. A. Árbitros: Carlos Esteban Jaramillo, Jorge Suescún y Andrés E. Ordóñez. 
suficiente por sí misma para restarle validez a este condicionamiento, aunque, como se verá, su aplicación al caso es innecesaria.

Las alusiones a estas doctrinas jurisprudenciales que giran en torno a la teoría de las cláusulas abusivas se hacen con insistencia en que, como ya se dijo, no han aludido expresamente al tema de los deberes recíprocos de información, si bien es cierto que, al menos en principio, y no obstante que en muchos casos la calificación de abusiva de una determinada cláusula no excluye la posibilidad de que la misma haya sido objeto de una negociación o acuerdo expreso en que haya intervenido el adherente, al origen de cualquier entendimiento al respecto, se encuentra la idea de que de haber sido adecuadamente informado, el adherente no hubiera aceptado la cláusula considerada abusiva.

b. La jurisprudencia colombiana específicamente relacionada con el tema del derecho a la información

En primer lugar es pertinente reseñar un reciente fallo de la Sala Civil de la Corte Suprema de Justicia, en el que se hace una mención específica del deber de información del asegurador, por lo menos dentro del contexto de un planteamiento general, relacionándolo con el carácter recíproco que debe darse a la aplicación del principio de la buena fe en el contrato de seguro. Dice así el citado fallo ${ }^{38}$ :

Y al mismo tiempo es bipolar, en razón de que ambas partes deben observarla, sin que sea predicable, a modo de unicum, respecto de una sola de ellas, v. gr.: el tomador del seguro, ya que el asegurador predisponente, entre otras conductas a su cargo (positivas y negativas), debe abstenerse de introducir en el clausulado -que someterá a consideración de su cocontratante- cláusulas abusivas (cas. civ. del 2 de febrero de 2001; exp. 5670) y, en general, llegado el momento respectivo, honrar la palabra empeñada, cumpliendo para dicho fin la prestación asegurada, lo que supone estricto apego al postulado en referencia, en su vertiente objetiva (vid.: cas. civ. del 19 de abril de 1999, exp. 4929, en la cual la Sala preconizó que la buena fe es "un postulado de doble vía, que se expresa -entre otros supuestos- en una información recíproca").

Igualmente debe mencionarse a este respecto, siempre referido al campo del seguro, el fallo del 19 de mayo de 1999 que había sido citado antes ${ }^{39}$, que también hace referencias muy puntuales sobre el tema del deber recíproco de información que incumbe a las partes, concretamente en el tema de las circunstancias que rodean el estado del riesgo:

Corte Suprema de Justicia, Sala Civil. Sentencia del 2 de agosto de 2001, M. P.: Carlos Ignacio Jaramillo, exp. 6146, proceso ordinario de Dolly Mejía Montes contra La Nacional Compañía de Seguros de Vida S. A.

39 Corte Suprema de Justicia, Sala Civil, exp. 4923, M. P.: José Fernando Ramírez G. 
La declaración de asegurabilidad puede ser dirigida o espontánea. La primera se traduce en un cuestionario concreto sobre lo que es relevante para el asegurador en relación con la situación del riesgo. La espontánea se expresa en una solicitud genérica de información que el asegurador plantea al tomador sobre hechos y circunstancias del riesgo que a juicio del solicitante resulten significativas para el asegurador.

En ambos casos el deber de información existe, pero en el segundo, o sea el de la declaración espontánea, necesaria y lógicamente se morigera su severidad, y por ende se reduce el nivel de exigencia para la configuración de la reticencia o la inexactitud como causales de nulidad relativa del contrato, porque si es el asegurador quien por razones técnicas cuenta con los elementos de juicio que permitieran precisar el tipo de información requerida, entonces debió acudirse a una declaración dirigida.

En vía de principio general lo que la norma reclama es lealtad y buena fe, pues este es un postulado de doble vía en esta materia, que se expresa en una información recíproca: el tomador debe ofrecer al asegurador todos los elementos de juicio que para este resulten necesarios para decidir si asume o no el riesgo, y a su turno el asegurador debe asesorar e informar al tomador de todas las circunstancias que conoce dado su profesionalismo y que puedan orientar la voluntad de aquél.

4. En la interpretación de los contratos de adbesión

Una sentencia paradigmática de la Sala Civil de la Corte Suprema de Justicia, proferida el 12 de diciembre de $1936^{40}$, aludía ya a avances muy definidos en el tema de la interpretación de los contratos de adhesión que tenían relación directa con los deberes recíprocos de información, particularmente a la distinción pregonada por DEREuX entre cláusulas esenciales y cláusulas accesorias del contrato de adhesión, afirmando: "Respecto de las primeras no hay inconveniente en aplicar el principio según el cual todo contrato es ley para las partes, pero cuando se trata de las otras cláusulas, de las accesorias, a las cuales el adherente no les ha atribuido mayor importancia, porque las considera destinadas simplemente a regular los puntos de detalle de la convención, debe admitirse que ellas no son oponibles al adherente sino en cuanto se limiten a precisar y complementar las cláusulas esenciales, y en ningún caso en cuanto modifiquen el alcance del contrato".

Asimismo, citando algunas decisiones jurisprudenciales de la Corte de París, señala igualmente la aplicación del principio de prevalencia de las condiciones particulares (manuscritas) sobre las generales (impresas), en caso de contradicción entre ellas.

No obstante, tampoco en esta sentencia la Corte tomó la decisión de declarar la ineficacia de una cláusula contractual basándose en el hecho de ser ella 
abusiva, o por implicar incumplimientos de los deberes del asegurador relativos a la información. Simplemente se limitó a aplicar el viejo principio del Código Civil de interpretación de las cláusulas ambiguas del contrato en contra de quien las ha redactado.

Sobre este punto debe citarse también la sentencia de la Sala de Casación Civil de la Corte Suprema de Justicia del 13 de diciembre de 1962, que optó por considerar inválida una disposición del reglamento del concurso del 5 y 6 incorporado como condiciones generales del contrato de juego, mediante la cual el Hipódromo quedaba facultado para negar el pago del premio en caso de que no se hubiera recibido en sus oficinas el correspondiente formulario registrado por un sellador autorizado, sobre la cual dice ERNESTO RENGIFO: "De manera especial se quiere destacar de este litigio la distinción que hizo el Tribunal prohijada por la Corte Suprema de Justicia en sentencia de 12 de diciembre de 1936 con ponencia de EDUARDO ZULETA ÁNGEL, entre cláusulas principales y cláusulas accesorias en un contrato y la manera como se relacionan" ${ }^{\prime \prime}$.

Finalmente, debe citarse en este aparte la sentencia de la misma Sala Civil de la Corte Suprema de Justicia del 8 de mayo de $1974^{42}$, en la cual no solamente reitera la aplicabilidad para la interpretación de los contratos de adhesión de los tres principios clásicos a los que había aludido la sentencia de diciembre de 1936, a saber: la interpretación de las cláusulas ambiguas contra quien las ha distado, la prevalencia de la intención de las partes sobre el tenor literal de las palabras utilizadas y la prevalencia de la cláusula que parezca expresar mejor la intención del adherente cuando existen dos contradictorias, sino que agrega a los anteriores el criterio de equidad, impulsado según el fallo por la escuela aristotélico-tomista y que es el que para la Corte en este caso "más exactamente se ajusta a la naturaleza de la estipulación y el que mejor garantiza a las partes su derecho".

Este agregado contenido en esta sentencia marca sin duda un precedente importante que va más allá de lo que antes e incluso después ha dicho la Corte en torno a la interpretación de los contratos de adhesión, y permitió a la Corte decidir, frente a una póliza de cumplimiento de un contrato de juego de carácter estatal, despojar de valor una cláusula contractual que establecía que el siniestro se entendería causado "tan pronto como la aseguradora sea notificada de las resoluciones administrativas que declaren el incumplimiento del contrato o de alguna de sus estipulaciones, o de la imposición de multas o sanciones previstas en el mismo". 
5. En cuanto a la prevalencia de las condiciones acordadas

sobre las condiciones contenidas en la póliza una vez expedida

En un laudo arbitral particularmente interesante, proferido con fecha 17 de septiembre de $1974^{43}$, se encuentra un antecedente claro de aplicación del principio de prevalencia de las condiciones acordadas en la etapa precontractual sobre las consignadas finalmente como condiciones generales de la póliza finalmente expedida por el asegurador, combinado con el principio de prevalencia de la cláusulas manuscritas o mecanografiadas sobre las cláusulas impresas, a partir de la utilización del principio tradicional de interpretación conforme al cual debe estarse más a la intención de los contratantes que al texto literal de las palabras utilizadas en el contrato.

Algunos apartes de este laudo son los siguientes:

ii) Los antecedentes de la póliza n. ${ }^{\circ} 9559$ señalan como objeto inequívoco "las existencias de dinero dentro o fuera de caja fuerte", sin que este enunciado aparezca demarcado en ellos por el concepto de propiedad. Concretamente, la solicitud de seguro que es su antecedente más inmediato y por virtud de estipulación convencional forma parte integrante de la póliza, delimita en los mismos términos la proporción de la entidad asegurada que traduce su intención contractual. Por tanto, si se pretende invocar las cláusulas generales de la póliza para definir la intención de los contratantes, y con ésta, el ámbito del seguro, habrá de concluir con la jurisprudencia y con la doctrina que las condiciones particulares, manuscritas o mecanografiadas, prevalecen sobre las condiciones generales impresas, porque aquellas traducen mejor la voluntad inmediata de las partes al celebrar el contrato.

A este respecto dice la Corte: "Entre dos cláusulas incompatibles el Juez puede preferir la que parezca expresar mejor la intención del adherente" (G. J., XLIV, 678-680).

Y FARIÑA expresa: "1392. Cláusulas impresas y manuscritas.- Con toda frecuencia, además de las cláusulas que forman el impreso de la Póliza, añaden las partes otras cláusulas manuscritas, ampliando o restringiendo el texto de las primeras. Las cláusulas manuscritas se ha dicho acertadamente que "son la traducción inmediata hecha por los mismos contratantes de su propio pensamiento" y por ello deben obtener preferencia sobre las impresas. Este es un principio admitido unánimemente por la jurisprudencia. Las cláusulas dactilografiadas se consideran equiparadas a las manuscritas" (FRANCISCO FARIÑA. Derecho comercial marítimo, IV, 46).

iii) Antecedentes tan diáfanos en cuanto a la delimitación objetiva del amparo, que recogen tan ostensiblemente el común designio de los contratantes, no pueden en-

43 Laudo arbitral proferido el 17 de septiembre de 1974, dentro del conflicto surgido entre Banco de Bogotá y la Aseguradora Colseguros S. A. y otros. Árbitros: Hernando Morales Molina, Jorge Vélez García y Efrén Ossa Gómez. 
tenderse desvirtuados por una mención tangencial, rutinaria, en un documento que estaba llamado a protocolizar el acuerdo y a determinar las condiciones a que debía sujetarse su ejecución. Cabría observar, además, que si la mención del concepto de propiedad consignada en la póliza, hubiera entrañado un designio voluntario de la Compañía enderezado a restringir unilateralmente el ámbito del seguro, cuando ya éste se hallaba en curso, habría que interpretarla como un elemento contrario a la buena fe contractual, a la rigurosa lealtad que en este género de negocios jurídicos debe presidir las relaciones de las partes.

6. En cuanto a la necesidad de claridad y precisión de las condiciones de la póliza relativas a las circunstancias de exclusión del riesgo

Otro destacable antecedente jurisprudencial, en el cual puede verse un esfuerzo tendiente a preservar el deber de información del asegurador frente al tomador del seguro, es la sentencia del 29 de enero de $1998^{44}$, mediante la cual la Sala Civil del la Corte Suprema de Justicia se abstuvo de reconocer la exclusión de riesgos que una compañía de seguros consideraba haber sustraído del amparo, por el hecho de que esas supuestas exclusiones no estaban consignadas de una manera clara y precisa. Esta sentencia, adicionalmente, llama la atención, al señalar los principios de solidaridad y colaboración que están implícitos en un contrato como el de seguro, como criterios auxiliares de interpretación de sus cláusulas. A esta sentencia corresponden los siguientes apartes:

Así, pues, uno de los elementos que identifican este esquema es la obligación "condicional" que contrae la referida empresa aseguradora, consistente en ejecutar la prestación prometida si llegare a realizarse el riesgo asegurado, obligación que por lo tanto equivale al costo que frente al "siniestro" debe ella asumir y de igual modo representa la contraprestación a su cargo, correlativa al pago de la prima que recibe del tomador, siempre en el bien entendido que la susodicha obligación es producto sobresaliente de un contrato que en tanto concebido para desempeñar una función bienhechora y no de simple pugna entre intereses económicos antagónicos según lo apunta con acierto un afamado expositor (JOAQuín GARRIGUES. Contrato de seguro terrestre, cap. 2, num. II), tiene un doble fundamento en la idea de buena fe extrema-uberrimae fidei contractus- y en la idea de solidaridad, nociones ambas que lejos de quedarse en loables aspiraciones teóricas de las que el comercio suele no ocuparse con la atención necesaria, son ricas por el contrario en consecuencias prácticas cuando se trata de resolver los problemas, de no poca importancia por cierto, que con mucha frecuencia se presentan en torno a la manera apropiada como han de ser interpretadas, y también aplicadas, las cláusulas contenidas en los documentos contractuales al tenor de los cuales se rige por principio cada relación asegurativa en particular. 
Siguiendo estas orientaciones, ha sostenido esta corporación que siendo requisito ineludible para la plena eficacia de cualquier póliza de seguros la individualización de los riesgos que el asegurador toma sobre sí (G. J. CLVIII, 176) y que por lo tanto, en este campo rige el principio según el cual la responsabilidad asumida en términos generales como finalidad del contrato no puede verse restringida sino por obra de cláusulas claras y expresas, "... El artículo 1056 del Código de Comercio, en principio común aplicable a toda clase de seguros de daños y de personas, otorga al asegurador facultad de asumir, a su arbitrio pero teniendo en cuenta las restricciones legales, todos o algunos de los riesgos a que están expuestos el interés o la cosa asegurados, el patrimonio o la persona del asegurado agregando que es en virtud de este amplísimo principio "que el asegurador puede delimitar a su talante el riesgo que asume, sea circunscribiéndolo por circunstancias de modo, tiempo y lugar, que de no cumplirse impiden que se configure el siniestro; ora precisando ciertas circunstancias causales o ciertos efectos que, suponiendo realizado el hecho delimitado como amparo, quedan sin embargo excluidos de la protección que se promete por el contrato. Son estas las llamadas exclusiones, algunas previstas expresamente en la ley..." (Cas. Civ. del 7 de octubre de 1985, sin publicar), exclusiones que por su propia índole, limitativa de los riesgos asumidos por el asegurador, requieren ser interpretadas con severidad en una concienzuda tarea que se oriente, de una parte, a establecer su justificación técnica, y de la otra a precisar el alcance de dichos riesgos, conforme a reglas de carácter legal o convencional, luego no le es permitido al intérprete, so pena de sustituir indebidamente a los contratantes, interpretar aparentemente el contrato de seguro para inferir riesgos que no se han convenido, ni para excluir los realmente convenidos; ni tampoco hacer interpretaciones de tales cláusulas que conlleven a resultados extensivos de amparo de riesgos a otros casos que no sólo se encuentren expresamente excluidos sino que por su carácter limitativo y excluyente son de interpretación restringida" (Cas Civ. del 23 de mayo de 1988, sin publicar).

En similares circunstancias es de destacar la sentencia del 14 de diciembre de $2001^{45}$, en la cual se abstuvo la Corte de reconocer validez a cláusulas que establecían exigencias de conducta para el asegurado, que para el asegurador constituían garantías ofrecidas por aquel, sobre la base de que no existía suficiente claridad y concreción en cuanto a la naturaleza de dichas exigencias.

Tan sólo debe agregarse en torno al alegado incumplimiento de la obligación asumida por el asegurado en virtud de la cláusula 2. ${ }^{a}$ del contrato, que si se atiende cabalmente lo estipulado en ella, únicamente puede considerarse como garantía -para los efectos específicos que consagra el artículo 1061 del Código de Comercio-, la disposición contenida en el inciso tercero de dicha condición, no así la incorporada en los dos primeros [...] Si se interrelacionan o articulan-como debe ser-los tres incisos de la cláusula segunda en cuestión, claramente se deduce que ella responde,

45 Corte Suprema de Justicia, Sala de Casación Civil. Sentencia del 14 de diciembre de 2001, exp. 6230, proceso ordinario de Trujitrillas y Cia. Ltda. contra Seguros La Andina S. A. y otras. 
prevalentemente, al propósito -o necesidad- de establecer un mecanismo para determinar, $a b$ initio, el monto de la prima a pagar, puesto que, en el aparte segundo de la mencionada estipulación, se estableció que a falta de la declaración, "la compañía aplicará para cada mes de amparo no declarado, los límites pactados" [...] de donde se colige que por el incumplimiento de ese compromissum, no puede predicarse la terminación del contrato -figura de interpretación restrictiva-, so pretexto de haberse violado una garantía. No es ajeno para la Sala que en el acápite tercero de la cláusula mencionada, el asegurado-ciertamente-garantizó que indicaría a la compañía el valor real de las existencias amparadas; pero si se tiene en cuenta el contenido "objetivo y gramatical" de las otras disposiciones [...] todo con sujeción a las reglas contenidas en los artículos 1618, 1620, 1621 y 1622 del Código Civil, no puede menos que concluirse que, stricto sensu, la obligación asumida por el asegurado de suministrar por escrito a la aseguradora y en un plazo determinado, una declaración que precise el valor de las existencias diarias amparadas [... no tiene alcance distinto al de poder establecer el valor de la prima a pagar por parte de aquel, por lo menos con arreglo a lo consignado en la supraindicada estipulación.

\section{En cuanto a la necesidad de que las garantías tengan relación con el riesgo}

Puede considerarse igualmente, como una manifestación de la protección al derecho a la información del tomador del seguro, la posición tomada por la Sala Civil de la Corte Suprema de Justicia recientemente, en sentencia cuyo ponente fue Carlos Ignacio Jaramillo, en el sentido de que, no obstante establecer el Código de Comercio la obligatoriedad del cumplimiento de las garantías establecidas dentro del contrato de seguro, sean ellas o no consubstanciales al riesgo, según los términos utilizados por el artículo 1061 del Código, no podrían considerarse válidas las que no tuvieran una relación específica con el riesgo. A esta sentencia del 30 de septiembre de $2002^{46}$ corresponden los siguientes apartes:

... la garantía será sustancial al riesgo si se exige como presupuesto determinante -o basilar- de la asunción de éste por parte del asegurador e, insustancial en caso contrario, en el que podría exigirse, entre otros cometidos, con la confesada y precisa misión de preservar el equilibrio técnico que, respecto de la relación aseguraticia, en línea de principio rector, debe existir entre el riesgo y la prima, sin que por ello esta exigencia se torne anodina o estéril, como quiera que la ausencia de sustancialidad, de plano, no quiere denotar trivialidad o nimiedad, expresiones de suyo divergentes. En todo caso, sea o no sustancial, stricto sensu, el asegurador al redactar o concebir los términos de la estipulación de garantía a la que posteriormente adhiere el tomador, debe obrar con sumo cuidado y prudencia, con el fin de que su alcance y contenido, en manera alguna, lesione el acerado postulado de la lealtad contractual (correttezza) o genere un desarreglo significativo en torno a los derechos y obligaciones que surgen para las partes en virtud de la celebración del contrato, porque en tales eventos, como 
se anticipó, la cláusula contentiva de dicha promesa podría tornarse abusiva, en contravía del postulado de la buena fe -objetiva-y, claro está, del ordenamiento jurídico, y de la jurisprudencia que, con ahínco, propenden por su destierro, por entenderla contraria a la "justicia contractual" -en su genuino sentido- y, de paso, transgresora de caros derechos, dignos de tutela, en sede judicial [...] Sea o no sustancial, en los términos ya reseñados, debe tener o guardar -alguna- relación con el riesgo( ), esto es, con el suceso incierto que no depende exclusivamente de la voluntad del tomador, asegurado o beneficiario (art. 1054 C. Co.), que es asumido por el asegurador, a voces del artículo 1037 del estatuto mercantil, puesto que de lo contrario, ello se prestaría para la incubación de abusos y conflictos que, al unísono, eclipsarían la teleología bienhechora de la institución del seguro. Sobre el particular, está de acuerdo la communis opinio patria( ). Tanto es así que el artículo en comentario, al proclamar la sustancialidad o insustancialidad, lo hace de cara al riesgo, como quiera que éste es el punto de referencia empleado por el legislador vernáculo -en lo pertinente-, lo que denota, entonces, que en cualquiera de los prenotados supuestos, incluso el de la insustancialidad, el riesgo debe hacer presencia, así sea moderada o sutilmente. Y es que ciertamente no puede concebirse en el contrato de seguro, in toto, una desconexión plena o absoluta entre la garantía y el riesgo, pues aquella puede ser o determinante en la asunción de aquel por parte del asegurador o bien servir para el mantenimiento cabal del equilibrio técnico, a la par que de la ecuación: riesgo-prima Si ello no fuere así, cumple memorarlo, algunas de las pólizas de seguros podrían ser, como lo fueron en el pasado en el viejo continente, verdaderas "selvas de garantías" - para emplear un descriptivo término utilizado en la doctrina( ) -, en las que cualquier infracción trivial, intrascendente o irrelevante de parte del tomador, serviría de pretexto al asegurador para no honrar la palabra primigeniamente empeñada, con las letales consecuencias que ello generaría en la vida de la relación negocial y, consiguientemente, en quiebre frontal del arraigado principio de la conservación del negocio jurídico (pervivencia in negotio). Por último, ella debe cumplirse estrictamente [...] Ahora bien, descendiendo al análisis del presente caso, una vez efectuadas las precedentes consideraciones generales, indispensables para fijar el recto entendimiento del artículo 1061 del Código de Comercio, materia de censura casacional, estima la Sala que el Tribunal [...] en puridad, no interpretó erróneamente el artículo en referencia, en cuanto consideró, en esencia, que cualquiera que fuera la naturaleza específica de la garantía, ella "tiene que tener alguna vinculación con el riesgo", habida cuenta que tal afirmación se encuentra en armonía con el alcance y sentido de la norma antes citada, tal y como se examinó. Empero, el Tribunal también consideró que el incumplimiento de la garantía "debe significar un incremento de probabilidad de ocurrencia del siniestro o del daño que de él dimana. Así lo ha entendido la doctrina y es la interpretación que se acomoda al precepto trascrito y a la esencia teórica de las garantías" (se subraya), afirmación que a juicio de la Sala, sí constituye una interpretación que no está en estricta consonancia con el artículo 1061 del Código de Comercio, por cuanto la norma no condiciona la configuración del incumplimiento de la garantía -ni in integrum, ni in partis-, al incremento en la probabilidad de ocurrencia del siniestro como lo entendió el Tribunal, hermenéutica que, por plausible que pudiera resultar, le agrega -o insufla- un condicionante inexistente, no sólo en su contenido actual - de lege data-, sino también respecto de la historia fidedigna de la norma inter- 
pretada, aludida precedentemente, en prueba inequívoca de su etiología legislativa [...] Dicho en otros términos, el artículo 1061 del Código de Comercio, a manera de plus, no exige que inexorablemente deba existir una íntima, estrecha e indisoluble relación-o comunión- con el riesgo, concretamente en lo tocante con el incremento en la probabilidad de realización del mismo, toda vez que es una cautela que, de jure condito, no demandó la norma en estudio, constituyéndose en un aditamento de origen extra-legislativo, por respetable y loable que sea. Ya se expresó, abundando en razones, que incluso la garantía insustancial frente al riesgo asegurado debe ser cumplida en forma estricta -interpretación avalada por los antecedentes del precepto en cuestión-, luego, si el tomador o asegurado, según el caso, se abstienen de realizar el débito prestacional al que se encuentran obligados en virtud de la garantía otorgada -o lo realizan incorrectamente-, habrán incumplido -en principio- la lex contractus, por manera que tal conducta, inicialmente reprobable, facultará al asegurador para pedir la anulación del contrato o su terminación, según fuere el caso, sin que sea necesario para configurar la anunciada inejecución negocial, que ésta se traduzca inequívoca e invariablemente, es decir en todos y cada uno de los casos, en un perceptible aumento en la posibilidad de realización del riesgo asegurado.

\section{En cuanto a los efectos de las labores de promoción y propaganda}

Del estudio ya citado José FERNANDO TORRES ${ }^{47}$ vale la pena tener en cuenta que allí se cita un fallo de la Corte Constitucional ${ }^{48}$ en el cual se expresó: "las ofertas, propaganda y promoción de las compañías de seguros, en materia de salud, y de las empresas de medicina prepagada, en los cuales se prometen ciertos beneficios generales o una determinada cobertura con el mismo carácter general, se incorporan al contrato que se celebre y obligan a la compañía que los ofreció. Solo este principio salvaguarda la buena fe en la relación contractual e impide que las personas resulten engañadas e inducidas a error al suscribir conductas de esta naturaleza"; más adelante precisó: "si la compañía en su propaganda [...] ofrece cierta cobertura y por esa causa una persona decide tomar la póliza, aquella está obligada en los términos de la oferta, que si son desconocidos, modificando sus alcances, ya en ejercicio del contrato y causando daño o amenaza a derechos fundamentales, dan lugar a que ante los jueces de tutela la empresa deba responder, cobijando todo aquello que prometió a los eventuales tomadores del seguro".

Un planteamiento diferente ha hecho la Sala Civil de la Corte Suprema de Justicia, al cual también se alude en el estudio de TORRES, y consiste en la eventualidad de que se comprometa la responsabilidad extracontractual de la persona que efectúa una propaganda engañosa o falsa. A esta sentencia corresponden los siguientes apartes ${ }^{49}$ :

47 J. F. Torres. "Deberes de información en la etapa precontractual a cargo del asegurador y del candidato a tomador", Memorias del XXIII Encuentro Nacional de Acoldese, cit., 116 y 117.

48 Corte Constitucional. Sentencia T-118 de 2000.

49 Sentencia del 13 de diciembre de 2001, exp. 6775, M. P.: Manuel Ardila Velasquez. 
Así que -y para abordar sin pérdida de momento el punto al que se quería llegar-, independientemente de la obligatoriedad de la oferta, cuando la invitación a contratar se realiza por conducto de una publicidad no puede, no debe, descartarse un eventual daño a sus destinatarios y su condigna reparación, si es que publicidad tal no se hace con apego a la sinceridad y seriedad que es de esperarse, de modo de inferir que la confianza del consumidor ha sido traicionada. Nadie discutiría hoy por hoy que al consumidor le asiste el derecho a estar informado, y ojalá bien informado. Ya incluso existen normas positivas que lo requieren sin atenuantes, verbigracia los artículos 20 y 78 de la Carta Política, donde de un lado se confiere rango constitucional al derecho a recibir información veraz y, de otro, se confiere a la ley la misión de controlar la información dada en la comercialización de los bienes y servicios ofrecidos y prestados a la comunidad, en protección de los derechos colectivos, y el Decreto 3466 de 1982, que en lo pertinente prescribe que toda información que se dé al consumidor acerca de los componentes y propiedad de los bienes y servicios que se ofrezcan al público "deberá ser veraz y suficiente" razón por la cual se priven las leyendas y la propaganda comercial que "... no corresponda a la realidad, así como las que induzcan o puedan inducir a error respecto de la naturaleza, origen, el modo de fabricación, los componentes, los usos, volumen, peso o medida, los precios, la forma de empleo, las características, las propiedades, la calidad, idoneidad o la cantidad de los bienes o servicios ofrecidos", disponiendo en consecuencia, que todo productor "... es responsable por las marcas y leyendas que exhiban sus productos (bienes y servicios), así como por la propaganda comercial de los mismos, cuando su contenido no corresponda a la realidad o induzca a error al consumidor"; y se prevé, además, que para la correspondiente indemnización de perjuicios, los afectados puedan recurrir a los trámites previstos para el proceso verbal consagrado en el Título xxIII del Código de Procedimiento Civil, con las adiciones procesales que en dicho estatuto se establecen, todo lo cual puede válidamente ubicarse en la fase precontractual, por cuanto ésta comprende, itérase, un conjunto de relaciones y de contactos entre las partes, cuya relevancia puede ser diversa, según el avance de la negociación (con el nacimiento eventual de una relación vinculante) y no solamente la oferta, como una etapa de mayor acercamiento entre los interesados.

Esta que pudiéramos llamar otra dimensión de la responsabilidad extracontractual en la que puede incurrir un empresario, en el campo de la propaganda o la publicidad que hace de sus productos, se ubica en un campo más general y abstracto pero no es de descartar eventualmente frente al contrato de seguro, siempre y cuando se haga una debida armonización con las normas que regulan la oferta. Creemos, no obstante, que son dos campos diferentes de acción jurídica, el uno se ubica en un plano estrictamente extracontractual y el otro dentro de las reglas propias de un negocio jurídico muy característico, como es el de la oferta.

\section{EL PROYECTO COLOMBIANO DE ESTATUTO DEL CONSUMIDOR}

Es indudable que el estatuto del consumidor y del usuario que se estudia actualmente en el Congreso Nacional, si llega a ser aprobado siguiendo de cerca el 
proyecto que es objeto actualmente de debate, va a significar un cambio importante en cuanto se refiere al entendimiento que viene dándose normalmente entre nosotros a las cláusulas generales de los contratos de adhesión y en general a los que rigen las relaciones de consumo. Vale la pena mencionar algunos de los dispositivos más relevantes que se encuentran asociados a la preservación del deber de información del empresario frente al consumidor o usuario, cuya aplicación al contrato de seguros no está exceptuada conforme al texto del proyecto:

5.4.1. - El condicionamiento de la validez de los contratos de adhesión (art. 35). Se condiciona esa validez, entre otros a la información suficiente, anticipada y expresa al adherente sobre la existencia, efectos y alcances de las condiciones generales. A la utilización del idioma español. A la claridad, concreción e integridad de las condiciones generales y a la utilización de caracteres tipográficos visibles. A la trascripción o resumen de las normas legales de referencia. A la no inclusión de espacios en blanco.

5.4.2.- Se consagra en su artículo 36 un listado de cláusulas prohibidas en los contratos de adhesión, dentro de las cuales se encuentran las siguientes, indudablemente calificadas como tales por cuanto implican violación al deber de información que pesa sobre el empresario que ofrece un contrato de adhesión:

a) Las que estén escritas en idioma diferente al oficial, o cuyos caracteres no sean legibles a simple vista.

b) Las que imposibiliten, limiten, exoneren o anulen la responsabilidad del proveedor por inadecuada o insuficiente información sobre los peligros o condiciones de utilización de los bienes o servicios.

c) Las que autoricen al proveedor a modificar unilateralmente el precio, las tarifas o las condiciones inicialmente pactadas, sin que se conceda al consumidor un correlativo derecho a resolver el contrato en caso de que se sienta afectado por dichas modificaciones.

d) Las que prevean la posibilidad de cesión del contrato por parte del proveedor sin consentimiento del consumidor.

5.4.3.- Se consagra en el artículo 38 la prevalencia de las condiciones particulares sobre las generales.

Resulta notable además que, dentro de este contexto, el artículo 39 del proyecto disponga:

El hecho de que una o varias cláusulas de un contrato hayan sido negociadas, no obsta para la aplicación de lo previsto en este capítulo. 
5.4.4.- El artículo 40 establece un listado de cláusulas abusivas que sanciona con ineficacia, indicando que se tendrán por no escritas, entre las que se incluyen, las que prevean la cesión del contrato por parte del proveedor sin consentimiento del usuario, las condiciones generales de los contratos que reúnan los requisitos señalados en la ley, y las cláusulas que autoricen la modificación unilateral del contrato de compraventa o modifiquen la oferta o desconozcan vicios redhibitorios contemplados en el Código Civil, dentro de las promesas de compraventa.

Es indudable que la adopción de un estatuto de este tipo significará una nueva era, frente a los desarrollos ciertamente muy tímidos que se han llevado a cabo por vía jurisprudencial, dentro de la normatividad vigente hasta hoy. 